Article

\title{
Becoming a Traditional Village: Heritage Protection and Livelihood Transformation of a Chinese Village
}

\author{
Rui Jun Qin ${ }^{1, *(1)}$ and Ho Hon Leung ${ }^{2}$ \\ 1 College of Ethnology and Sociology, Guangxi University for Nationalities, Nanning 530006, China \\ 2 Sociology Department, SUNY College at Oneonta, Oneonta, NY 13820, USA; hohon.leung@oneonta.edu \\ * Correspondence: qinruijun0717@gmail.com
}

check for

updates

Citation: Qin, R.J.; Leung, H.H. Becoming a Traditional Village: Heritage Protection and Livelihood Transformation of a Chinese Village. Sustainability 2021, 13, 2331. https:// doi.org/10.3390/su13042331

Academic Editor: Osmud Rahman

Received: 24 January 2021

Accepted: 18 February 2021

Published: 21 February 2021

Publisher's Note: MDPI stays neutral with regard to jurisdictional claims in published maps and institutional affiliations.

Copyright: (c) 2021 by the authors. Licensee MDPI, Basel, Switzerland. This article is an open access article distributed under the terms and conditions of the Creative Commons Attribution (CC BY) license (https:/ / creativecommons.org/licenses/by/ $4.0 /)$.

\begin{abstract}
This paper seeks to explore the sustainable development of contemporary Chinese villages by taking Nalu Village in China as a case study. Ethnographic in-depth interviews and observations are used to investigate the transformation of the rich history and heritage in the village. The research and analyses are informed by a multi-dimensional framework of sustainable development. The research finds that the state's naming the village as a "Chinese Traditional Village" has promoted local rural tourism, which plays an important role in improving the visibility of the village, increases the income of the villagers, and enhances a stronger sense of attachment and satisfaction of the villagers. The pride of the villagers in turn makes them cherish the history of their village. This paper argues that this pride becomes the capital or incentive for the villagers to sustain its continuity.
\end{abstract}

Keywords: traditional villages; heritage protection; rural tourism; sustainable development; livelihood transformation

\section{Introduction}

\subsection{Background on Chinese Rural Development}

Since the 1990s, China began to implement the process of urbanization. Increased number of rural populations migrated to the city in search of better employment prospects. Urbanization in China increased from $18 \%$ in 1978 to $56.1 \%$ in 2015 [1,2]. In 2019, the China National Bureau of Statistics reported that the increase rose to $60.6 \%$ [3]. The number of villages in China reduced from 376.22 million in 1991 to 266.96 million in 2012; 1.104 million villages have vanished [4]. Rural sustainable development has never been an urgent priority in China's state agenda until recently.

With the rapid development of urbanization and industrialization, more and more villages are rapidly "hollowing out", even "vanishing" or disintegrating [5-7]. The outflow of population from rural areas raised deep concerns at all levels of governments regarding to two major issues: rapid disappearance of villages (a cultural and heritage issue) and shortage of farmers for food productions (a practical issue). These unsustainable development trends have attracted the attention of the government and academia.

China is still developing with more than half of the population as farmers. The Chinese authorities have continuously issued sixteen urgent documents, almost once a year, to promote the sustainable development of China's “Three Rural Issues (agriculture, rural, farmers)", since the beginning of the 21st century. Among the strategies to solve the problems in China, the protection and development of "traditional villages" have become more and more prominent in recent years. Those villages that have experienced the baptism of modernization are viewed with high vitality and development potential. People began to rethink the economic and cultural value of villages with rich histories and cultural value to resolve the issue of the "Three Rural Issues". 


\subsection{What Are Traditional Villages?}

Previously, the concept of a traditional village lacked specificity. Yet the term has been used and accepted by people in everyday usage. Some people also call it "ancient village", "old village", "characteristic village", and so on. In 2003, Feng Jicai, a famous Chinese writer, discovered that many traditional villages in China are like a thick ancient book, but they have disappeared before they could be read. He initiated the rescue project of Chinese folk cultural heritage in 2002 [8], and also proposed to protect ancient villages in 2012.

The government also recognizes the importance of protecting those old villages. In April 2012, the Ministry of Housing and Urban-Rural Development (MOHURD), Ministry of Culture, National Cultural Heritage Administration (NCHA), and Ministry of Finance issued the notice on assessing the potential of these villages. In this notice, the official definition of traditional village appeared for the first time, which is defined as: those formed earlier, have rich traditional resources, have certain historical, cultural, scientific, artistic, social and economic values should be protected [9]. In August of the same year, the MOHURD and other departments issued a system to evaluate villages in a proposal entitled "Traditional Village Evaluation and Identification Index System (Trial)" [9].

The definition of "traditional village" by the above organizations has become the basic official framework for organizing the investigation, selection, evaluation, definition, registration, and formulation of protection and development measures of traditional villages. In 2016, the NCHA and the China Foundation for Cultural Heritage Conservation also launched the "action to save old houses". China's decision and actions to protect traditional villages encompass the entire country. By 2019, 6819 villages have been included in the list of Chinese traditional villages in five phases [10]. Jiangsu, Fujian, Shaanxi, and other provinces have established a list of their traditional villages. The number of these local traditional villages is even greater.

The selection of traditional villages gives equal weight to tangible heritage and intangible heritage. Judging from the list of selected Chinese traditional villages, this initiative not only attaches importance to the traditional architectural and landscape values of villages, but also pays attention to the intangible cultural heritage values of villages. Such efforts are in line with the six cultural and four natural criteria for the selection of World Heritage in the United Nations" "Operational Guidelines for the Implementation of the World Heritage Convention" [11], and also echo the missions of International Council on Monuments and Sites (ICOMOS), which is to advocate cultural and social diversity around heritage and to facilitate the mobility of members coming from impoverished countries [12]. The identification of traditional villages in China has opened the practice of the consensus that landscape heritage and cultural heritage should be protected and utilized at the same time.

Then, this development raises an intriguing question. What has transformed the village that now has been given the state title of "traditional village"? This paper explores the sustainable development of villages based on the state's heritage protection policies through the use of Nalu Village, Guangxi Province, as a case study.

\section{Literature Review}

\subsection{Sustainability: Conceptions and Implementations}

\subsubsection{The Contemporary Understanding of Sustainability}

Robertson defines sustainability as an "enduring into the long long-term future; it refers to systems and processes that are able to operate and persist on their own over long periods of time" [13] (p. 25). The concept of sustainability is increasingly relevant due to the pronounced environmental degradation caused by massive industrialization and excessive resource-based human consumption [14]. In such a short span of time, sustainability has become a buzzword across industrial, political, economic, and social spheres [15] (pp. 9-31). It is critical to observe the notion of sustainability as rooted in socioeconomic structures that underlie all aspects of human life, which is also included in the research and practice of rural sustainable development. 
Although some argue that the contemporary sustainable development does require a personal level of comfort and acquisition brought by growing economic development, the depletion of the earth's resources is constantly offsetting people's hope of "subjectivity" and producing a sense of despair [16] (p. 19). While rethinking the development of industrial societies, the research on sustainability turns to focusing more on the wisdom of indigenous society on ecological restoration as a potential means to reverse global power dynamics [17] (p. 37).

\subsubsection{Sustainability of Heritage Areas}

The protection and utilization of heritage is a great opportunity for local sustainable developments. The protection and utilization of cultural heritage has not only a direct impact on the local income and employment production, but also a long-term impact on the potential of supporting the knowledge economy, being used as educational resources, stimulating creativity, developing cultural capital, or developing high-quality original products and services in the cultural sector, creative industries, and tourism [18]. In the aspect of heritage, tourists visiting heritage sites often indirectly induce the multiplier effect of tourism production when they consume in retail sector (souvenirs, food and beverage, books, photographic supplies, etc.) and in accommodation, catering, tour guide, transportation, leisure, beauty, or sports services [19-21]. The Małopolska region of Poland has adopted an innovative and multi-level approach in the connection between heritage, tourism, and development, which has improved the quality of life and image of the region [22]. Murzyn Kupisz believes that the attitude of local communities towards heritage, their understanding of heritage value and commercial potential, and their willingness to use heritage also have a multiplier effect on local sustainable development [23].

Sustainable development should not only consider the direct economic impact of heritage tourism and related projects, but also pay attention to its "human capabilities, survival of the institutional framework and creating society's capacity and capabilities for transitions to ecological, social, and environmental sustainability" [24] (P12). Some studies suggest that sustainability is not entirely related to environmental stress, but also to social and cultural aspects [25-27]. Murzyn-Kupisz sums up the general development paradigm, which stretches from economic growth, economic development, to socio-economic development, and the latest is sustainable development, and sustainable development is "the diverse uses of heritage for the needs of both contemporary and future generations, inter and intra general equity; an only party renewable resource" [18] (p. 117).

In recent years, the discussion on heritage and sustainable development has expanded to a more macro level. Barthel Boucher proposed that the cultural/heritage path can be a useful tool to solve the challenges related to sustainable environment, emphasizing the compromise between scientific views, moral values, and traditional conservation technologies, and regarding heritage as a kind of social welfare [28]. She claims that neoliberal values dominate the global heritage community (Rakic, Chambers, and Timothy also hold the same view $[29,30])$, and believes that heritage conservation should be redefined by extending the debate to climate change and sustainability [28]. Throsby (2009) proposed to deal with heritage tourism projects in a "holistic way", focusing on intergenerational and intergenerational equity, respecting the inherent diversity of heritage, maintaining the balance between natural and cultural ecosystems, and recognizing the interdependence among economic, social, and cultural systems [31]. The issue of heritage sustainability has extended to social justice and is committed to creating livable communities for all.

This sort of expanded research is reflected in rural areas, which is often manifested in the broader understanding and development of village resources, as well as the benefit distribution and the reuse values in the process. 


\subsection{Sustainable Development of Village}

\subsubsection{Holistic Protection of Natural Ecology}

Researchers have consistently evaluated the vulnerability of villages, especially traditional villages, as industrialization increasingly infringes upon the natural environment and agrarian frameworks for subsistence. The concern with sustainability arises even in a traditional village setting, because of the danger that is currently faced in the context of increasing deforestation and disintegration of soil quality, and developmental construction has also damaged natural ecosystems [32]. A study conducted in the Central of Himalaya by Maikhuri and others found that "linking traditional crops with economic development of the village of hill farmers through value addition adopting the traditional and modern appropriate technologies may be the suitable strategy to conserve these crops in-situ" [33] (p. 777).

Liu and others discovered that the ecology of villages in higher altitude tends to be more vulnerable [34]. From the perspective of landscape, Huang and others divided the vernacular cultural landscape into four processes: ecological, productive, daily and social life, spatial and religious landscape processes, and proposed a holistic approach to revive and rescue the ancient village in Yunnan, China [35]. Liu explored the protection of Chongqing traditional villages on mountains from the perspectives of restoring its architectural style, the improvement of the supporting facilities, landscape environment regulation, and so on, to glow the vitality and dynamism of traditional villages [36]. In sum, rural ecology usually balances the issue of development between the rural population and local natural resources [37].

Chang and others developed a model for the examination of ecological concerns, safety, and disaster prevention for rural development, with the international mechanisms for sustainability and eco-community assessment. This result may be used for dealing with issues such as rural development, the reduction of global warming, and the improvement of rural ecology and residential spaces [38]. Dumreicher's team carried out a 5-yearresearch study of "SUCCESS" in rural China, aiming at establishing future images under the premises of sustainability. They were more concerned about how to establish the importance of the rural environment and living space as a basis for the future of China [39].

\subsubsection{Design Education and Member Behavior}

Previous research demonstrates that members of the village can contribute to local sustainable development. Scholars generally pay attention to the participation and behavioral change of multiple human resources. The research led by Chambers and Ma confirmed that human resources were the core of sustainable livelihoods [40,41]. Focusing on elderly populations in retirement villages in Australia, researchers noted that most people of an older generation were interested in leading sustainable lifestyles, including investing their money in ways that would improve and protect the environment [42].

Fan and others suggested that reasonable educational level of rural members would also guide villagers to develop sustainable behavior patterns. Given the large number of urgent and unresolved issues in developing countries and rural areas, they argued it was essential to emphasize design education and encourage local design education and promote a positive loop in the rural ecology through local designs [43]. Hlalele advocated that creating space for harmonious and fluid co-existence between nature and humanity, in such a way that the contribution of learning practices exudes and expedites sustainability in rural ecologies, could contribute to sustainable village development [44]. In short, each specific village has a unique optimal sustainable development outcome. Both design education and member behaviors are critical elements to provide a solid framework for rural village development. 


\subsection{Heritage and Rural Tourism}

\subsubsection{Discover and Designate Heritage}

Many scholars coin rural tourism with sustainable development of villages. As Akpinar and other argued that agrotourism, a combination of agriculture and tourism, improved natural resources, and contributed to the development of rural area socially and economically [45]. Henderson observed that rural tourism always depended how to operate and manage rich local resources, such as heritage, since heritage is a unique selling point in tourist businesses. This would generate income like a theme park [46]. Rural tourism, or rural heritage tourism, constitutes a popular research framework for rural sustainable development.

Other scholars explore village development from employing the concept of heritage into their studies. Heritage is a broad concept [47]. Nijkamp and Riganti revealed that the concept of heritage is not given, but created by a community, by people who attach values to some objects, rites, languages, contexts, lifestyles, historic sites, and monumental buildings. Arguing from the perspective intergenerational equity [48], Nijkamp and Riganti further indicated that heritage needed to be passed on to others, just as protecting the environment for future generations was the requirement of sustainable development [48]

At a global scale, World Heritage Convention (UNESCO, 1972) has become a major driving force for the development of effective practices for heritage conservation and utilization. The World Heritage Convention unifies the protection of nature and cultural heritage in one document, and recognizes the way of interaction between man and nature, and the fundamental need is to maintain a balance between them [49]. The Budapest declaration (2002) defines the types of natural or cultural sites that can be considered for inclusion in the world heritage list [50]; the 31st session of the World Heritage Committee adopts New Zealand's proposal on increasing the role of communities in the protection of cultural heritage; this creates the strategic objective of the World Heritage Convention "Five Cs" (creativity, conservation, capacity building, communication) [51]. By 2018, there were 1121 properties in 167 countries/regions on the World Heritage Sites (WHS) list [52]. The Convention has played an important international role in the protection of cultural and natural heritage with outstanding universal value.

Kevin Williams found that there was evidence that World Heritage Site designation provided economic benefits and leverage at site level [53]. Nijkamp and others indicated that labeling something as heritage represented a value judgment, which distinguished that particular object from others, adding new meaning to it. They also found that cultural heritage helped developed people's identities, shaped communities and to this extent contributed to the creation of social capital [48]. Therefore, named heritage often paves the way for a new round of change and development.

The European Landscape Convention (2000) provides wider scope for the protection of natural and cultural heritage. It applies to the whole territory of the contracting party, covering natural, rural, urban, and suburban areas; whether ordinary or outstanding, urban or rural, land or water, as long as it involves landscapes that may be regarded as outstanding and daily or degraded landscapes, it can be included in the scope of protection and management, so as to enhance people's awareness of the value of living landscapes [54].

\subsubsection{Heritage Protection and Development}

After the discovery and designation of a site as heritage, how to protect and develop it usually becomes a concern that demands much discussion and negotiation. Lowenthal pointed out that heritage " . . is far from being fatally predetermined or God-given, [but] is in large measure our own marvelously malleable creation" [55] (p. 226). Harvey also shared the same point about heritage. He observed that heritage was not given but foremost a process of making which required a good practice with social responsibility [47].

The following scholars' observation on the nature of heritage creation can be found in cases that today's heritages around the world have been manipulated from different perspectives. Their reason is also based on the understanding of the values of heritage 
which are understood to be dynamic and perceived through different lenses [48]. As Hall argued, "It is us-in society, within human culture-who make things signify. Meanings, consequently, will always change, from one culture or period to another" [56] (p. 61). The question lies in the challenge of defining the authenticity of heritage. For example, some researchers warned that the increasing demand of tourism led to physical transformation of historic buildings. Loss of identity, authenticity and homogeneity of rural architectural heritage resulted [57]. This questions the negative consequences the authenticity of heritage tourism that would bring to the site. Some scholars believe that tourism will inevitably destroy and plunder the heritage [58,59].

The other concerns are energy efficiency and ecological environmental protection. Heritage based tourism can increase local financial revenue, promote employment, and also promote the protection of the environment, the restoration of the artistic and cultural heritage of rural space. Therefore, it is very important to reduce the operation cost for promoting the sustainable development of economy and environment. Serraino and Lucchia saved a fortified village with high heritage values. It was not used and in an advanced state of damage. This became a successful case to illustrate the important aspects of the installation of new touristic functions with conservation, energy efficiency, and landscape integration [60]. In another circumstance, tourism inherently brings economic revenue, but also causes environmental issues from pollution and a disintegration of the ecological focuses of local groups, especially in rural and traditional areas [61]. Moreover, some scholars argue that institutions must protect local indigenous groups' intended land use as a touristic attraction [57]. Thus, protecting the environment and natural beauty of a site is essential for the development of rural tourism.

Growth in tourism brings pressures on cultural resources; yet, it can also become an incentive to protect and enhance these resources [62]. Sustainable tourism and rural tourism are thereby inherently linked, as the systems are intertwined, and their mutual health depends on each other. Tourism brings in revenue while the sustainability increases the value to visitors and simultaneously creates a baseline of ecological protection [63]. Given the ferocity of competition in the tourism industry, tourism destination needs to maintain its unique tradition and identity; otherwise, it may experience the loss of tourists. From this standpoint, heritage must be supported by both authenticity and innovation. Henderson and others argued that heritage tourism could be a protector of culture and heritage [46].

The National Association of the most beautiful villages has demonstrated its advocacy that can be used as reference in rural heritage protection and tourism promotion. In 2012, the Associations, founded by France, Japan, Italy, Quebec (Canada) and Walloon (Belgium), listed 600 beautiful and outstanding villages [64]. This association establishes an international reference network for the protection, strengthening of culture and development of rural areas with low population density, continuously exchanging experiences and expertise, and encouraging regional, national, and international public authorities to provide all technical and financial assistance for the management and sustainable development of these territories [65]. The association is advocating an "immersive heritage" strategy that is helping villages enhance their tourism potential.

\subsection{Transformation and Sustainability of Rural Livelihood}

In addition to sustainably protecting heritage and developing rural tourism, other scholars argue that livelihood of the villagers cannot be ignored. Anti-poverty is still an important global issue. Seven hundred thirty-six million people lived below the international poverty line of US\$ 1.90 a day in 2015 [66]; the World Bank estimated that an additional 88 million to 115 million people would fall into extreme poverty in 2020, with the total rising to as many as 150 million by 2021 [67]. With the exception of China, more than half of all progress in poverty reduction has been lost [68]. However, there was 551.62 million living in rural areas in China by 2019 [69]. China has 800,000 villages-with one person out of seven on the globe living in a Chinese rural setting [39]. Their quality of living remains a concern of the Chinese government. Gao and others (2017) found that diversified and 
flexible economic developments could be achieved, in both ecological and economic terms. In the process of pursuing sustainable development, rural tourism not only helps to restore the local ecological environment, but also plays an important role in anti-poverty [70].

Furthermore, villagers and elites have always been important agents supporting rural sustainable development. Localized leadership is necessary to generate strong rural livelihoods while maintaining sustainable practices [71]. Li and others reported that the success of these villages relied on the integration and coordination of internal and external driving forces, the participation of key actors, negotiation and cooperation among key actors, and formation and development of rural networks [72]. Communal participation and an increased wealth for the region are two critical means of improving life for the local rural populace while creating attractions for tourists, such as Yuanjia in the Shaanxi Province, China [70].

China's rural sustainable development task has involved many stakeholders. In the Jinshan County of China, researchers exemplified how sustainable development could be a potent mixture of government and local network connection and planning: through diversifying crops and land usage, economic investment from political structures, including local and state government and educational tools for villagers [73]. At the higher governmental levels, Xue and others found that it was possible to adopt policies in the face of increasing pressure to reform with sustainability as the primary ideology; however, putting policy into action was far more contentious and problematic, especially in China [74].

New technology and local knowledge have important significance for rural livelihoods. Sustainable practices such as new renewable energy technologies can also bolster new economic investment and profitability for rural residents [75]. When these new technologies are put into effect, they benefit not only the local stakeholders of rural residents and their livelihoods in addition to the sustainability of the region, but they also aid the government in terms of increasing positive logistics in the given region [75].

In addition to inter-disciplinary and trans-disciplinary approach to sustainable development of villages, the local's knowledge must be taken into serious consideration, scholars argued [39]. Indigenous knowledge can be used and should be considered as a sustainable resource to be preserved and utilized to continually improve the natural environmental in rural regions [76]. In Yogyakarta and Indonesia, for example, where international tourism has increased in recent years, there is an important intertwining relationship between sustainability and tourism. Local knowledge and the unique use of natural resources make this destination unforgettable [77].

Furthermore, some scholars put forward more profound views, which fill a gap in the study of rural livelihood. Their views "inject a more thorough-going political analysis into the centre of livelihoods perspectives" [78] (p. 171). Scoones criticized the current research with livelihoods perspectives that they lacked engagement with processes of economic globalization and attention to power and politics; it also failed to link livelihoods and governance debates in development. Hence, he put forward that it was urgent "to articulate livelihoods perspectives with concerns of knowledge, politics, scale and dynamics" [78] (p. 183). Scoones also suggested four dimensions of a new politics of livelihoods: a politics of interests, individuals, knowledge, and ecology [79]. Together, these suggest new ways for rural sustainable livelihoods, potentially with profound implications for thinking and action.

The sustainability of rural development is a complex and multi-dimensional issue. The existing literature enlightens that we cannot think about the sustainable development of rural areas from a single perspective. A more comprehensive framework that guides a village's sustainable development could be more productive if elements from material and non-material resources, as well as the manpower and projects that leverage resources are well used in balance. Such a process at least connects the locals, the local government, and the state government with a long- term vision. 
The literature reviewed above shows that there are many possibilities for rural sustainable development. The perspectives and emphasis in the literature review have informed the research directions of this project which focuses on:

(1). How do different agents in China designate a village to be a "Chinese traditional village" and what influence does the labeling bring to the sustainable development of a designated village?

(2). How do local villagers adjust their thoughts and actions to engage in the practice of promoting local sustainable development and maintain the designation of "China's traditional village"?

The discussion of this paper attempts to evaluate whether Nalu Village could serve as a model of sustainable development of villages in China and shed light on a theoretical framework for development for other cultures and countries.

\section{Fieldwork and Research Methods}

\subsection{Nalu Village}

Nalu Village is located in the middle of the Guangxi Zhuang Autonomous Region in Southwest of China (Figure 1). Guangxi is one of the few provinces in China that has a high concentration of ethnic minority groups. There are 12 ethnic groups in the province where they retain a high level of autonomous governance. More than $90 \%$ of the residents in Nalu Village are also part of the Zhuang ethnic minority groups. Nalu Village is $30 \mathrm{~km}$ away from Xiangzhou County. It is located on the edge of Luoxiu River (Figure 2). It has $0.85 \mathrm{~km}^{2}$ of cultivated land, $0.47 \mathrm{~km}^{2}$ of paddy field, $0.23 \mathrm{~km}^{2}$ of farmland, and $1.33 \mathrm{~km}^{2}$ of woodland.

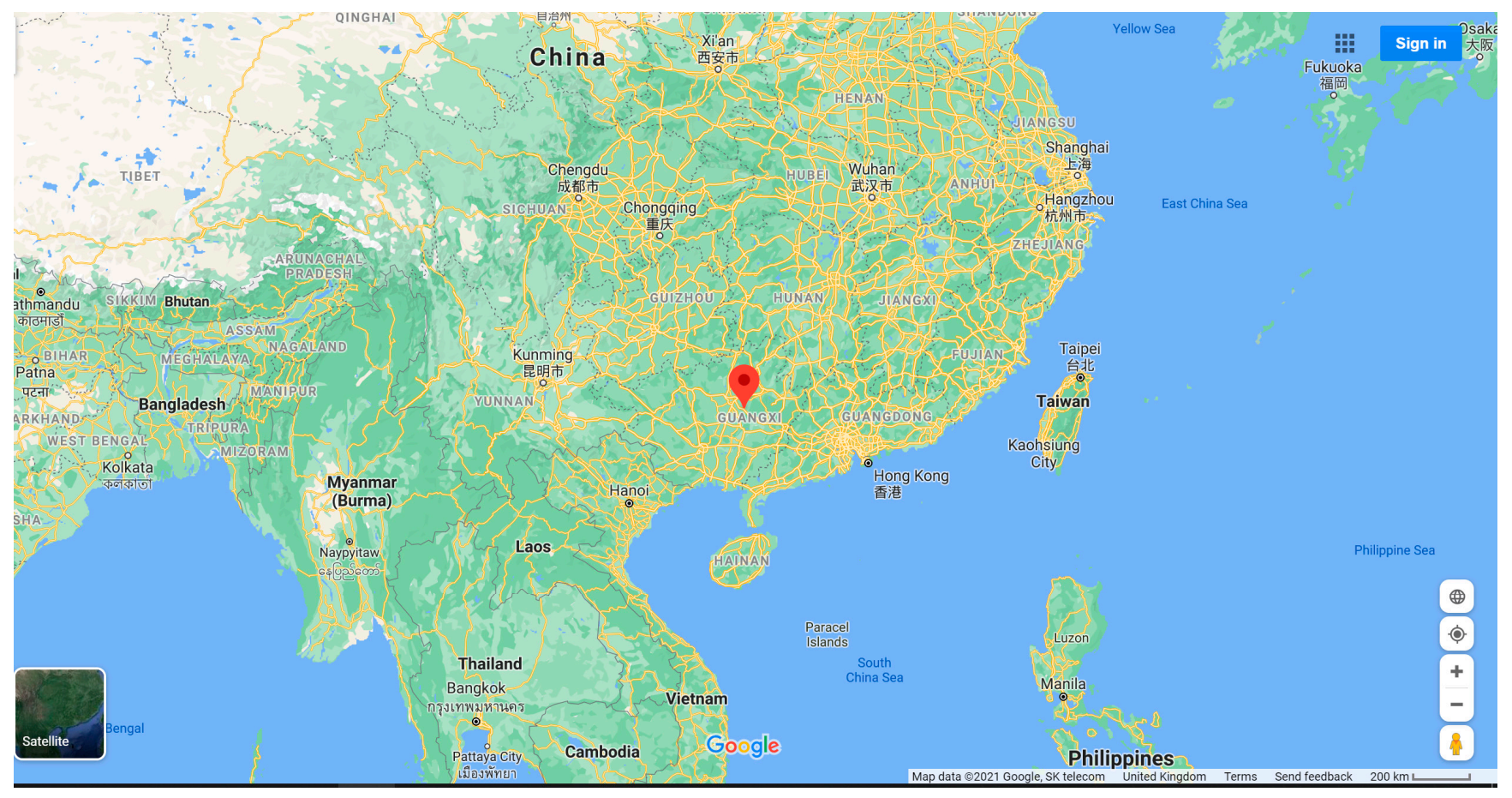

Figure 1. Nalu Village located in Guangxi Zhuang Autonomous Region, China. Source: Google Maps.

Nalu Village has a long history in the region. When Zhu Yuanzhang overthrew the Song Dynasty (960-1279) and established the Ming Dynasty (1368-1644), he appointed his sons or brothers and relatives in the form of vassal to govern the territory. Zhu Shouqian, the nephew and grandson of Zhu Yuanzhang, was the first king of Jingjiang in Guilin, Guangxi Province. In the late Ming Dynasty, the regime collapsed, and the army of the Qing Dynasty (1636-1912) went South. The study of Zhu family history absorbed the viewpoint 
of Professor Zhu, a historian and a descendant of the Zhu family, who indicated that the "Zhu's family fled to Nalu. After settling down, they kept a low profile and completed the transformation from aristocracy to farmer. After several generations of settlement, they finally had the ability to plan and build their own family garden in the middle period of the Qing Dynasty. At this time, they called themselves Nalu in Xiangzhou" [80]. The elders in Nalu often say, before the Zhu family moved here, that there was a small village called "Baizihang" not far from the current village. After the Zhu family settled down, the other villagers of "Baizihang" gradually moved to their present location and lived around the ancient houses, eventually forming the pattern of "nine families with different surnames in one village".

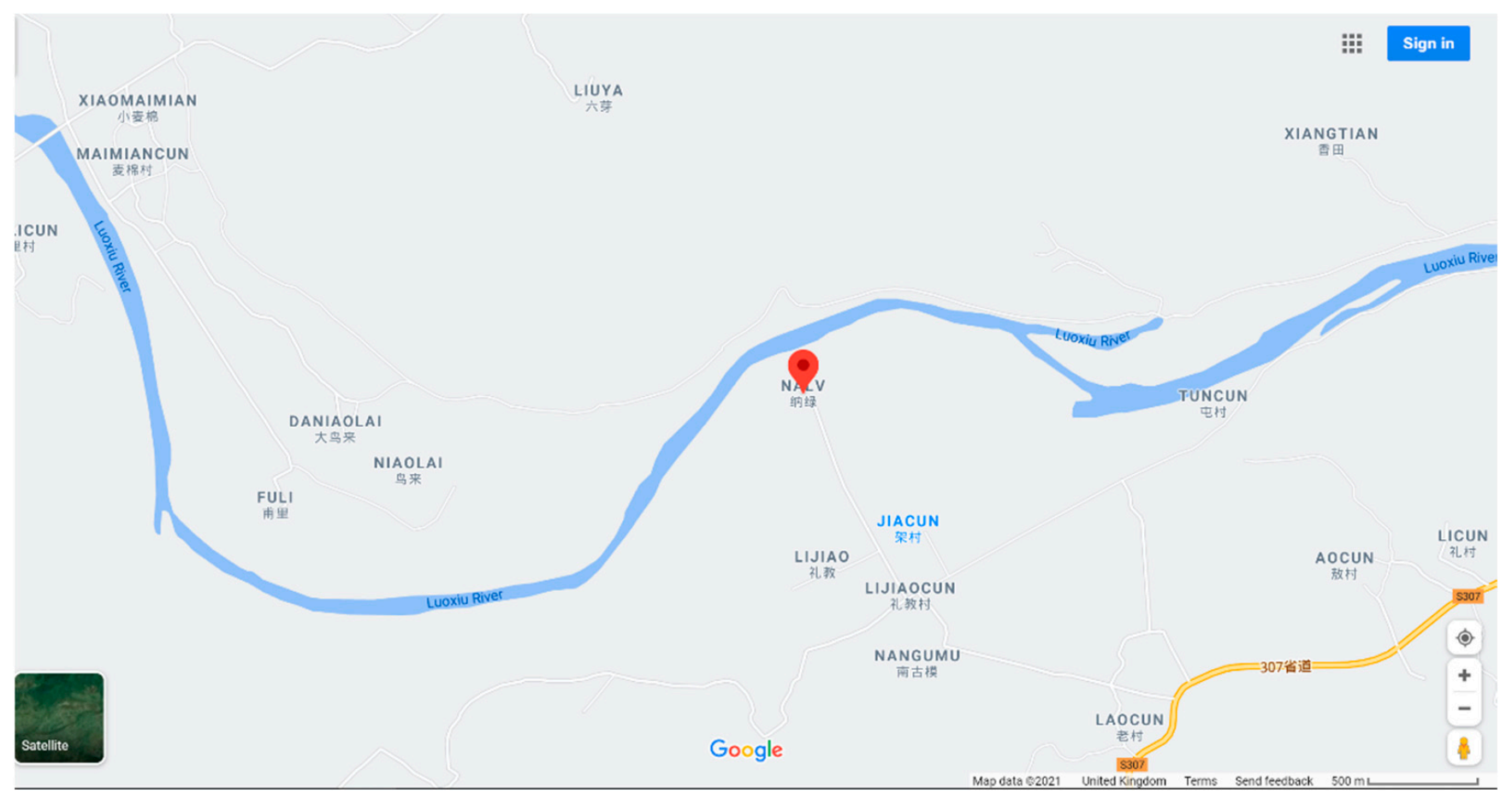

Figure 2. The specific location map of Nalu Village. Source: Google Maps.

More than thirty-six blue brick, tile, and wood structure buildings were built by Zhu's descendants, facing south, square and straight, with cornices and carved windows. Leaping fishes over a dragon and other ornaments decorate the top section of the main gate that leads to the house (Figure 3). The front courtyard wall of the main building is the screen wall, inlaid with the words "wish, longevity, blessing and auspicious star", showing the pattern of traditional Lingnan architectural style in China. All courtyards in the house provide public spaces for everyone to interact. Today, the remaining 24 old houses are basically in good structural condition. Because of its rich historical resources and cultural background, Zhu's ancient buildings have become an important core structural base for the transformation and development of Nalu Village.

\subsection{Material and Methods}

The ethnographic qualitative data were collected from a three-year fieldwork in Nalu Village. The techniques of semi-structured, in-depth interviews, and participant observations were used to collect qualitative data in Nalu Village between 1998-2020. Furthermore, extensive research about the village and its development was conducted on the government websites and archives. The research had also been informed by materials about the developments of Chinese villages available on different media including both online and hardcopy of newspapers and magazines, and relevant peer-reviewed literature. The purposive non-probability sampling and snowball sampling strategies were used to identify 
participants who had the knowledge about Nalu Village development. Seven local county and town government officials, 5 local village cadres, 16 local villagers, and 12 visitors were interviewed. Analytical induction was employed to help identify recurring themes from examining the collected data. Cross referencing among interview and observation data, secondary data from different websites and sources, and the literature were used to ensure accuracy of analysis.

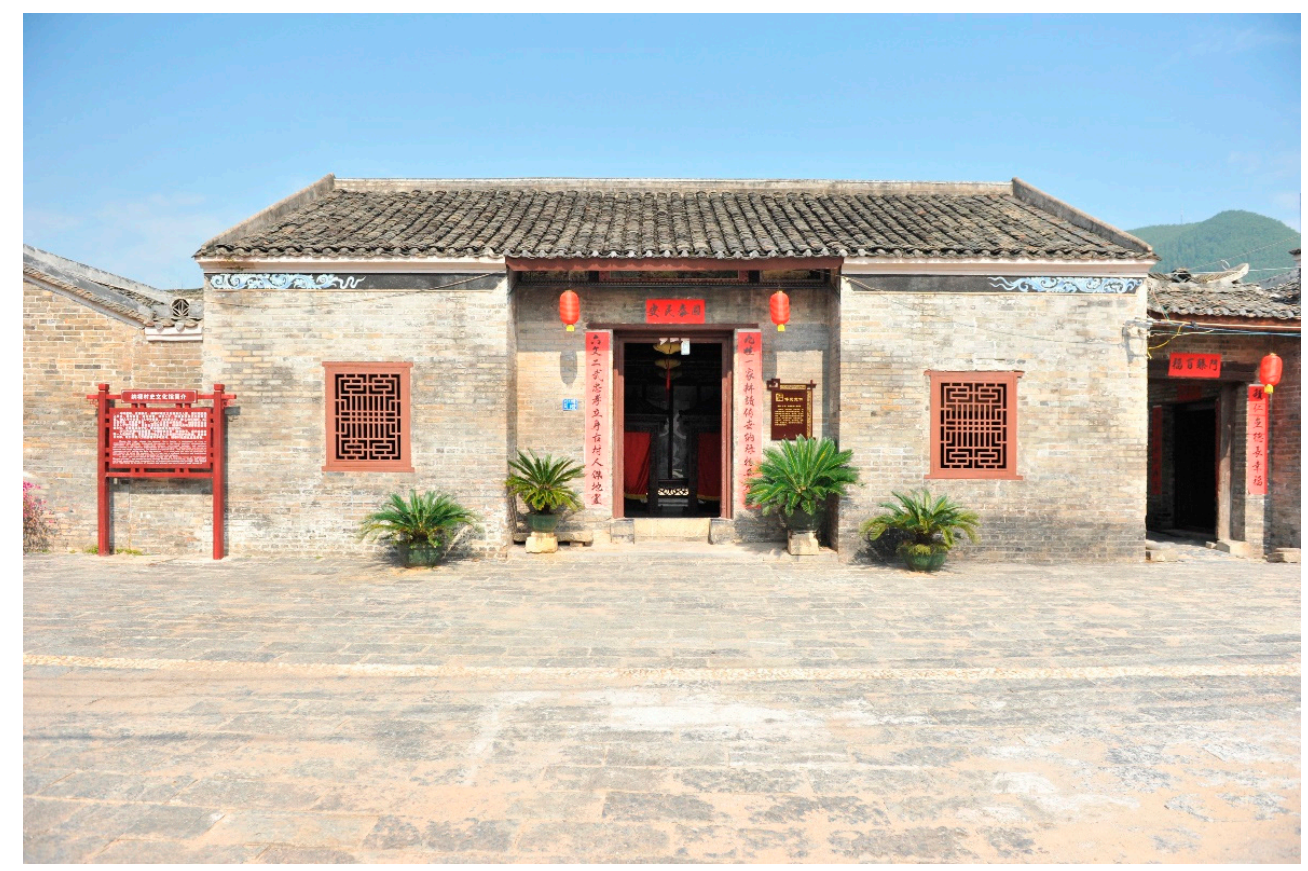

Figure 3. The main house of Nalu Village's ancient buildings.

\section{Becoming a "Traditional Village": The Protection and Development of Heritage}

In this section, the process of how Nalu Village became a "traditional village" according to the governmental criteria, especially about the initiative of local villagers and the positive promotion of local government, as well as the subsequent maintenance, protection and space construction process will be reported. The villagers' understanding and interpretation of Nalu Village's culture and history will be discussed.

\subsection{Beginning from an Initiation of Heritage Protection \\ 4.1.1. The Baptism of a Flood to Nalu Village}

In 2005, Nalu Village suffered an unprecedented flood, and many houses were destroyed. The former village head observed that "because most of the houses at that time were mud tile houses, the flood of Luoxiu River destroyed many houses, and the rice fields in front of the village were all filled with mud." He mobilized the villagers to rebuild their houses after the disaster. The provincial government granted subsidies to each family, and the banks also provided low interest loans. In less than two years, most of the villagers were able to live in new houses.

However, the villagers who lived in the new houses began to find that the old houses were getting dilapidated because they had been uninhabited. Villagers were distressed when faced with these situations. As early as in 2005, when the provincial government leaders visited Nalu Village to inspect the disastrous situation, they realized that Nalu Village had to be included in the historical and cultural protection project and proposed to attract investment and develop tourism. However, at that time, the villagers focused on the reconstruction of their homes, and felt that there was no need to consider the protection and development of the ancient houses. 
Before the devastating flood, Nalu Village experienced ongoing nationwide land reforms and housing policies in rural land system before and after the founding of the People's Republic of China [81]. Zhu's house had been redistributed to different residents many times. Many non-Zhu family members had lived in these old houses for a long time. Interviews revealed that no matter whether they were from the Zhu family or not, they all had affection toward the ancient house.

In 2011, people in Nalu Village recalled what they saw before the restoration that the alleys of the old houses had been neglected for many years, the gates had collapsed, the walls were falling off everywhere, and the tiled roof was leaking. Some villagers expressed their sadness with the following terms: "makes the heart cold", "tear comes with sad sentiment", and "a good old building unexpectedly suffers from such a disaster". They felt that they could no longer turn a blind eye to the continuing decay of the old house.

Therefore, under the leadership of Village Head Mr. Zhu, all the villagers spontaneously and jointly submitted an application to the government for the protection of these ancient buildings. The villagers wrote in the application report that "the Zhu's house in Nalu village was built in the late Ming Dynasty by the descendants of Jingjiang King in Guilin, which has a history of more than 400 years" [82]. They pleaded to the government that the authority should "pay attention to the maintenance of Zhu's house in all aspects, restore its true features, attract the interested parties to invest here, develop it into a tourist attraction, and prosper the economy of Xiangzhou county" [82] (p. 192).

In April 2012, the MOHURD, the Ministry of Culture, the State Administration of Cultural Relics and the Ministry of Finance jointly launched a survey about Chinese villages with a long history. At the end of the year, China announced the first batch of 646 selected villages that were qualified to be included in the category of "traditional village". Nalu Village was the very first village named in the list of Chinese Traditional Villages in Laibin City [82] (p. 194). This was the first time that China launched such a large-scale campaign to protect ancient villages.

\subsubsection{Actions to Restore and Protect Ancient Buildings}

Nalu Village received 3 million Yuan (about US\$ 460,000) of construction funds from the state for the protection and restoration of ancient buildings after being designated as a "Chinese Traditional Village" (Figure 4). Just like most other investments in heritages in China, this type of big project has been a government-led initiative [83]. The local government first carried out the protection and utilization by renting the ancient buildings under one contract. At that time, most of the owners of the ancient houses signed a lease with the county government. The houses were renovated and developed by the government and professional companies. The villagers were quite aware of the determination and ability of the state to protect villages. As of now, except four families which are still living in these old houses, all the other villagers leased these ancient houses to the government.

The local government contracted the specific construction tasks to professional companies. The restoration works were carried out to restore the original appearance of the ancient houses as much as possible. In the process of restoration, Nalu villagers' opinions and suggestions were consulted and adopted. According to some villagers, each building unit had at least one plaque at its most glorious time. In the middle hall of the ancestral hall, there was a 2-m long and 1.2-m wide plaque with the characters “Da Ya Tang" (大雅堂), which literally means "the great elegant hall". In the upper hall, there were warehouses on both sides of the ancestral hall, where there were 12 sedans, including four official sedans and four special "hovering" and "quiet" plates for senior officials. There were also eight flat sedans and various drums, gongs and flutes musical instruments for grand events and ceremonies. Although it is impossible to completely restore the old house according to its original appearance, the designers tried to inject the main "traditional" elements into the restoration and decoration of the old house (Figure 5). For example, the red lattice windows and wooden doors, as well as the shrine and ancestral tablet, traditional tables, chairs, and bed cabinets created the living scene of the folk houses at that time. 


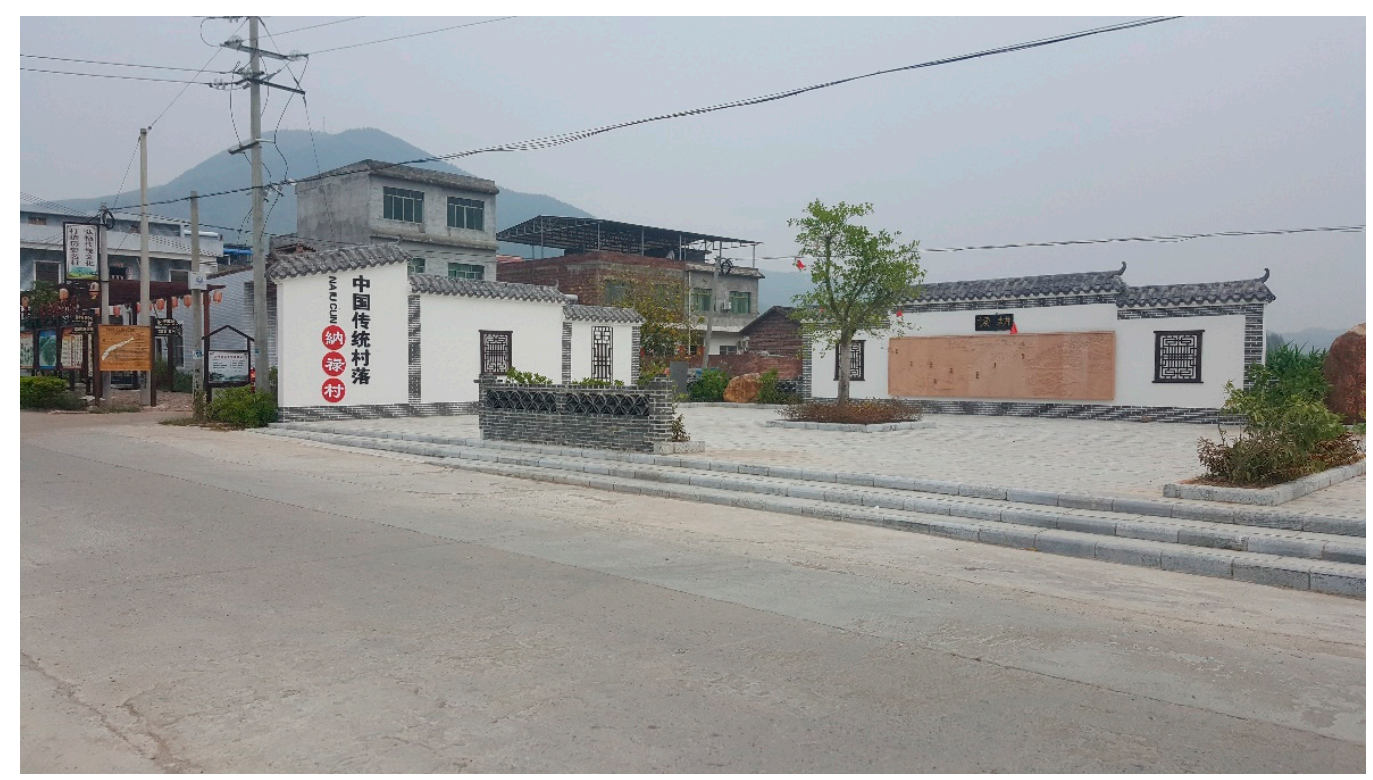

Figure 4. Naming Nalu Village as a "Chinese Traditional Village" presented clearly on a wall at the village entrance.

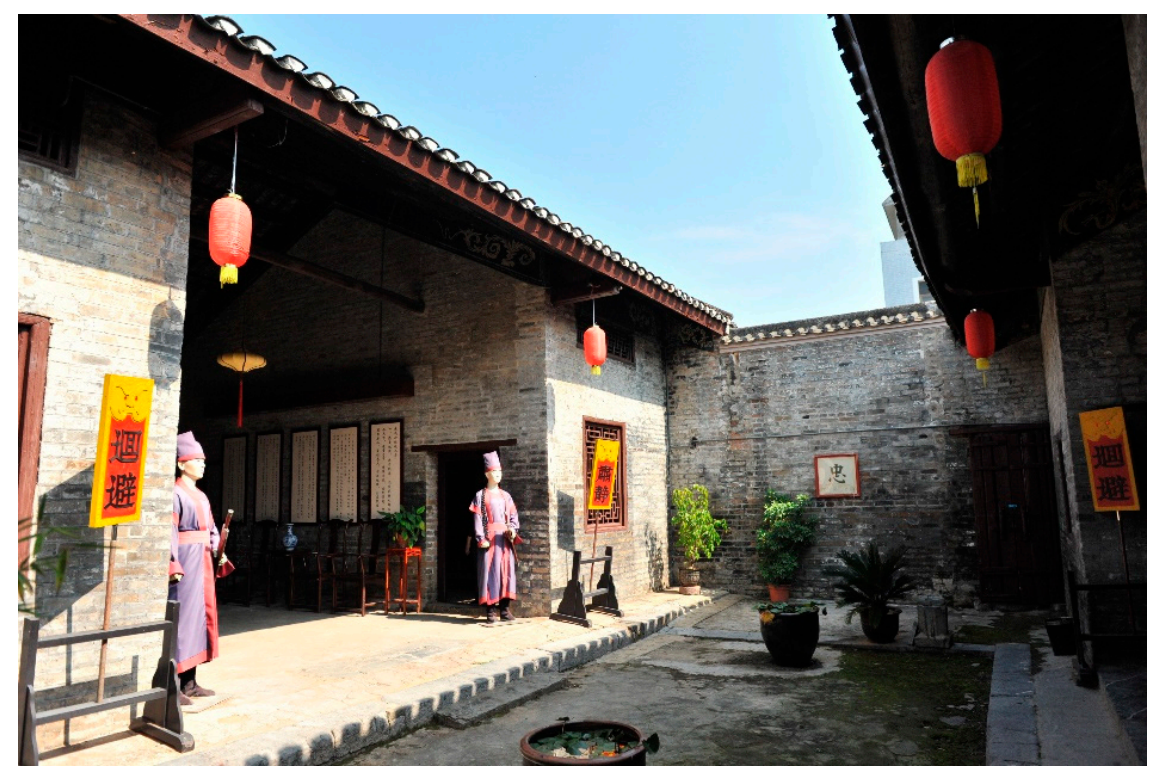

Figure 5. An ancient building decorated with traditional elements.

Even though concerns toward ancient villages began in the 1980s in China, it was not until the 1990s that the state took concrete action to the study of ancient villages [84]. With the largest and fastest urbanization process in human history, China's rural areas with a long history of farming have been declining day by day. People call for "keeping the sentiment of nostalgia". Due to limited financial resources, the preservation of heritage was not considered successful. The Ministry of Construction and the State Administration of Cultural Relics of the people's Republic of China launched the project to select "Chinese famous towns \& villages in history \& culture", which aims to preserve the towns and villages with great historical value or commemorative significance. So far, only a total of 799 towns/villages have been selected [85].

While China's economy has made great achievements, the state starts to pay more attention to ecological development and rural development. In 2007, the Chinese government proposed to "coordinate urban and rural development, promote the construction of new socialist countryside", and in 2013 proposed to build "beautiful countryside". It 
planned to invest 10 billion Yuan (about US $\$ 1548$ million) in three years to promote the protection of traditional Chinese villages. Each selected village would receive 3 million Yuan (about US\$ 464.4 thousand) from the national financial protection funds. China has entered a new era of protecting and developing traditional villages under the direction of the state [86].

\subsection{Development and Innovation of Heritage: From the Perspective of Rural Tourism}

The sustainability of the architectural and cultural heritage offers a wide number of tourism sites in rural areas. They fit in the beauty of the landscapes, in the architectural richness of secular buildings, in the exuberance of the gastronomy and in the local cultural tradition. After three years of restoration, the ancient buildings in Nalu Village became increasingly renown as a scenic spot in Guangxi (Figure 6). Just as Paul Selman claims that sustainable landscape planning requires the embedding of political and economic mechanisms that possess the continuous potential to reproduce valued places [87]. In this process, the local government and the villagers cooperated to develop new projects toward rural tourism. This mainly includes the special utilization of ancient buildings, the improvement of village infrastructure, the establishment of scenic spot and an area for traditional ecological agriculture experience, and the annual traditional tourism culture festival.

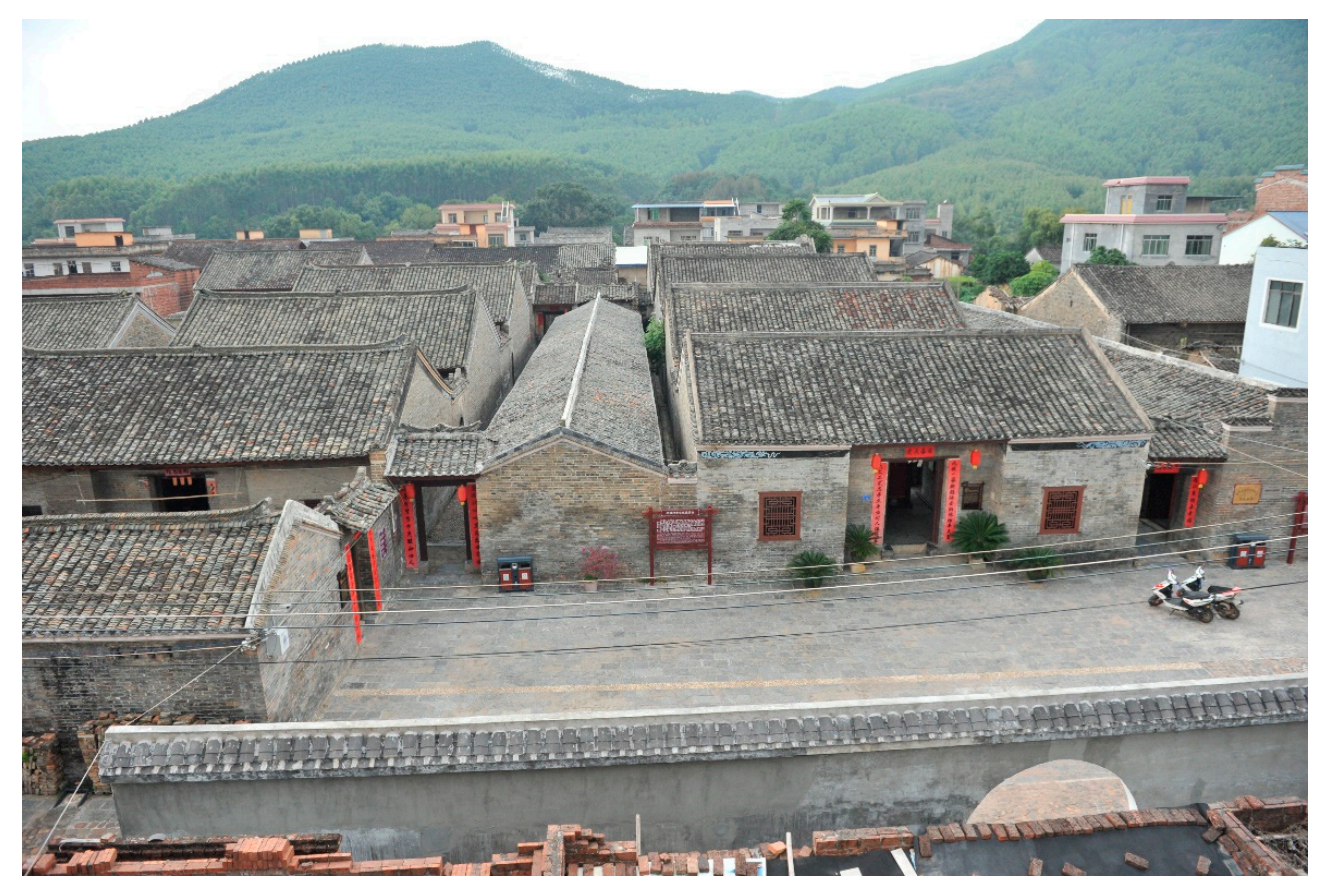

Figure 6. Ancient buildings in Nalu Village.

\subsubsection{Restoring the Traditional Space of Ancient Architecture}

How to make good use of the internal space in the resorted old houses had become a major concern. The local government explored the cultural connotation of Zhu's clan in Ming Dynasty from a broader historical perspective in the name of Zhu's descendants. First, it shows the relationship between the descendants of Zhu and Jingiiang King in Guilin. In the form of genealogy and hereditary table, the names of the whole Zhu family are listed from generation to generation, and pictures of tombs or large-scale worship of Zhu's ancestors are also displayed on the wall. These tell people that the descendants of Zhu family lived here and descended from a common ancestor who was Zhu Yuanzhang, the founder of the Ming Dynasty.

The name of the main hall is "Pei Guo Hall" (沛国堂) (Figure 7). It is the most important place in a home, where Zhu families gather together on regular basis. It is also a place to worship ancestors during various festivals. The sacred and daily life always meets 
in the hall, which constitutes a symbolic space for traditional Chinese families. A shrine is located in the end of the hall. In front of the shrine, there is a high footed table for ancestor worship. A couplet is displayed above the shrine to show the origin of the family and the respect to their ancestors.

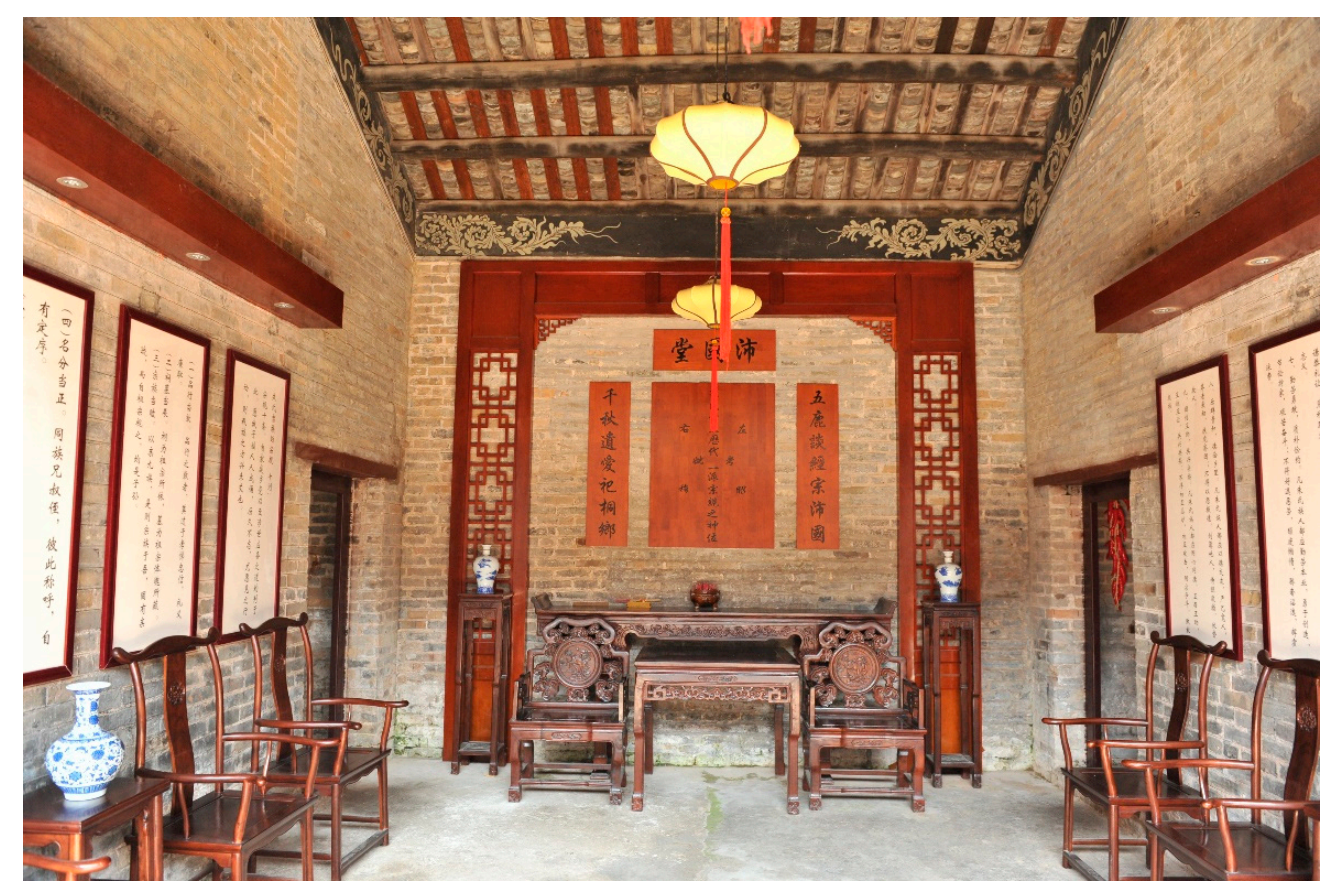

Figure 7. The restored and decorated main hall in an ancient building.

The hall is also decorated with mahogany furniture, and the rooms are also equipped with ancient beds, cabinets, tables and other daily necessities to create the appearance of a home of that era. These pieces of furniture and daily necessities, together with the vicissitudes of green bricks and tiles, off painted wood, and the unpaved ground in the middle create a nostalgic ambiance.

To some extent, it can be said that rural tourism needs diversified developments where tourists can appreciate the place from different perspectives. In this sense, the success of the tourist activity is closely linked to local resources, in their quantitative and qualitative expressions. The tourism development of Nalu Village has been recognized by tourists (Figure 8). A few selected tourists were interviewed for their impression of the village. $\mathrm{Mr}$. Wei said: "what impresses me deeply is the waterscape formed by the rivers around the ancient village, the long houses and alleys here and the legends of the descendants of the royal family of the Qing Dynasty." Ms. Qin, who accompanied him, showed appreciation of the pleasing atmosphere presented by "the stone road and the lanes of the houses with green bricks and white tiles." (Figure 9)

Mrs. Pan described that the houses there were very simple, full of sense of age and culture, and had a strong historical charm. Another visitor, Mr. Liang, was impressed and stated that "it is rare for an ordinary village to have such an intact old house under the impact of modernization. Their protection and development occur simultaneously. It incites a feeling of continuity without a sense of being conservative in an old and traditional way."

Mr. Liao, a writer, said that he often collected folk songs or other manifestations of local culture in Xiangzhou, where there were many subjects to write about. He wrote in a blog published in March 2017 that had been read more than 8000 times so far, and indicated that while walking in the ancient buildings of Nalu Village, experiencing the straight green bricks after three hundred years of vicissitudes, visitors from everywhere feel the heavy and unforgettable history [88]. 


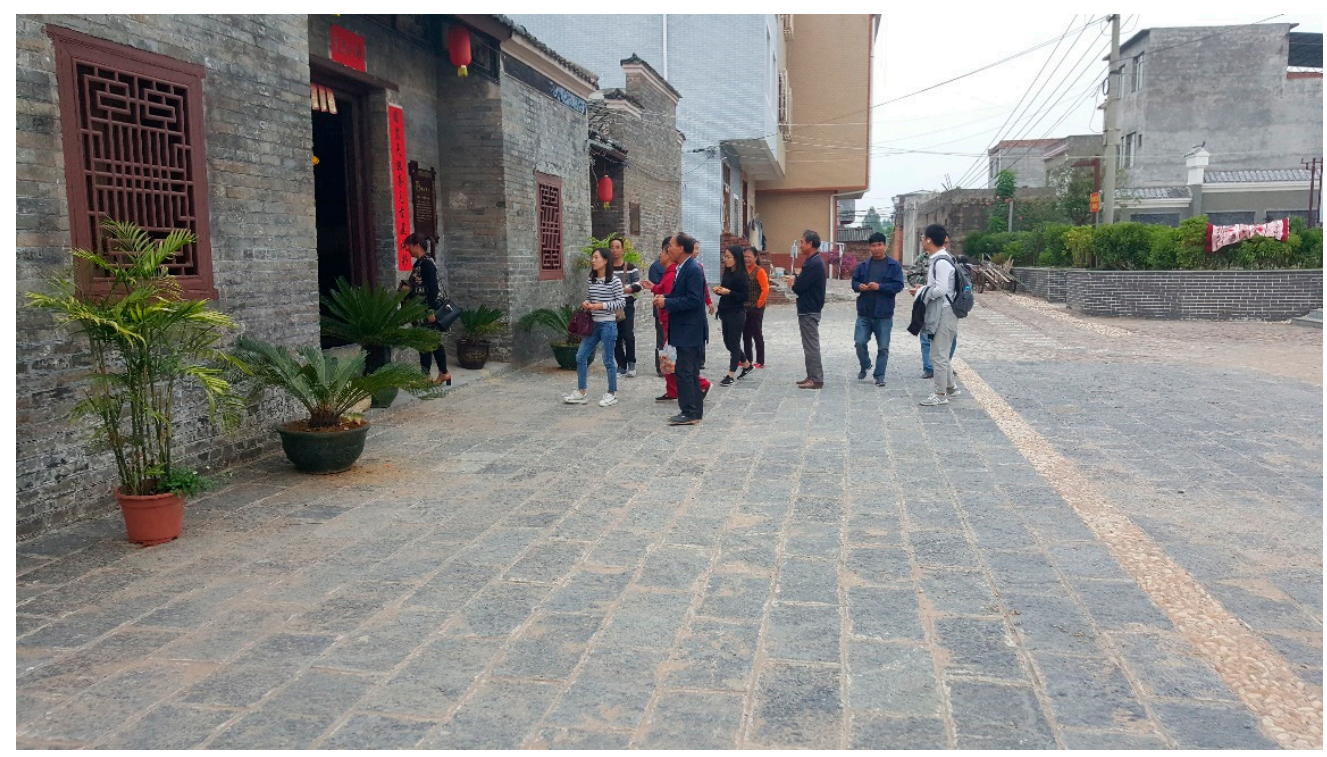

Figure 8. Tourists visiting the ancient buildings.

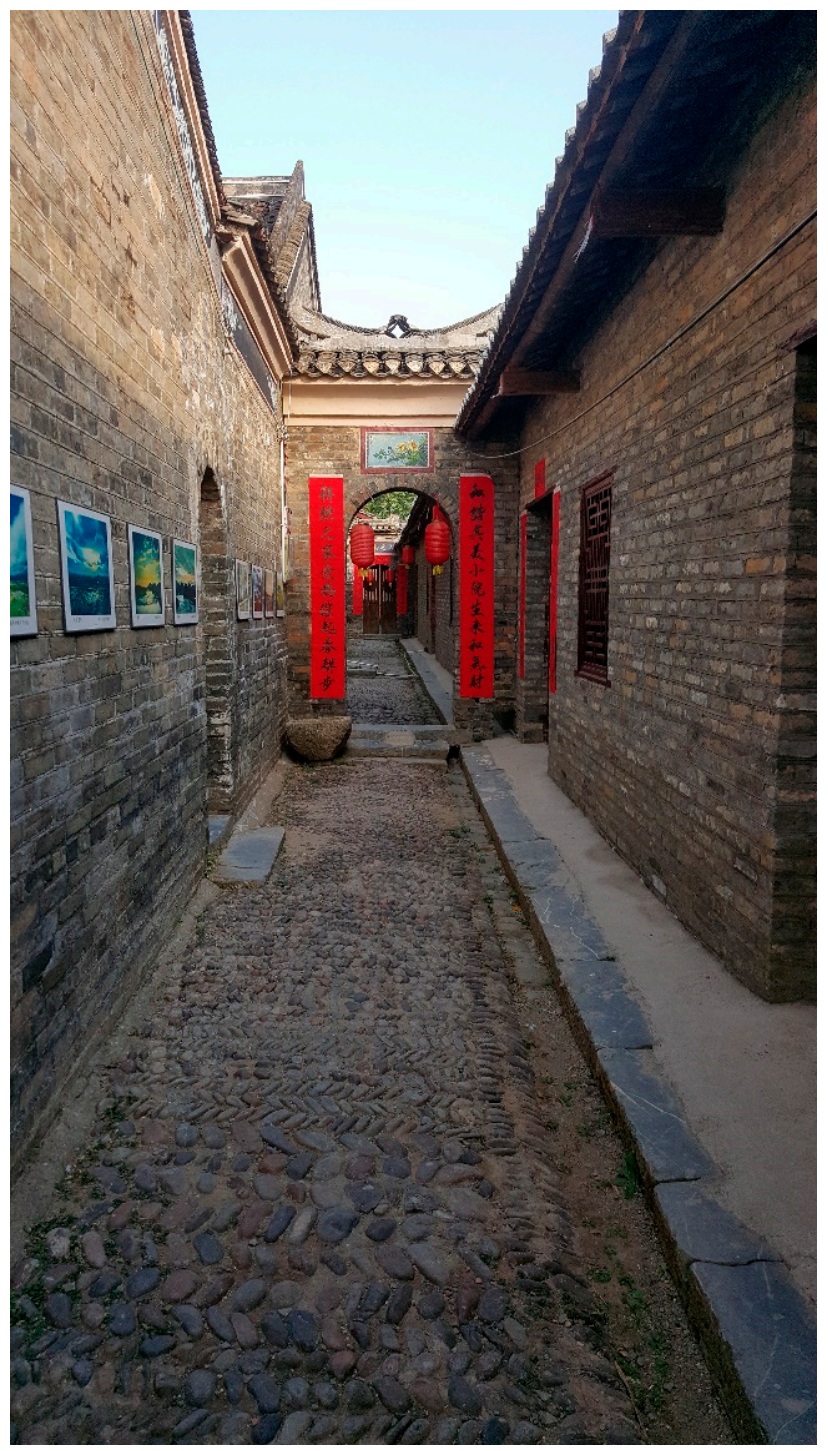

Figure 9. A laneway in ancient buildings. 
Ms. Qin, who had been engaged in financial management for many years, shared her perspective on the village. She said that Nalu Village was her grandmother's home, where she spent a lot of her childhood time. She wrote in her travel blog about Nalu Village in the following way: I believe I developed a strong affection toward the land and the nature out of my childhood experience in Nalu Village. This feeling creates a slight distance between me and the rest of the world. That makes me unique [89].

The local government turned a row of houses on the East side of the main building into a "farm culture exhibition hall" (Figure 10). The villagers named it "Village History Museum". It signifies the local farming culture, folk culture, ecological culture, and local special products with exhibits and it also shows the future development plan of Nalu Village. The government and the villagers try their best to put all the collected used and later abandoned agricultural tools and handicraft utensils, such as plows, rakes, hoes, sickles, baskets, dustpans, and so, on in this traditional space to create a museum. The collections are arranged in the space of ancient architecture, making it look like a space of the past. Besides that, farming culture, folk culture, and ecological culture are arranged in the repaired ancient buildings.

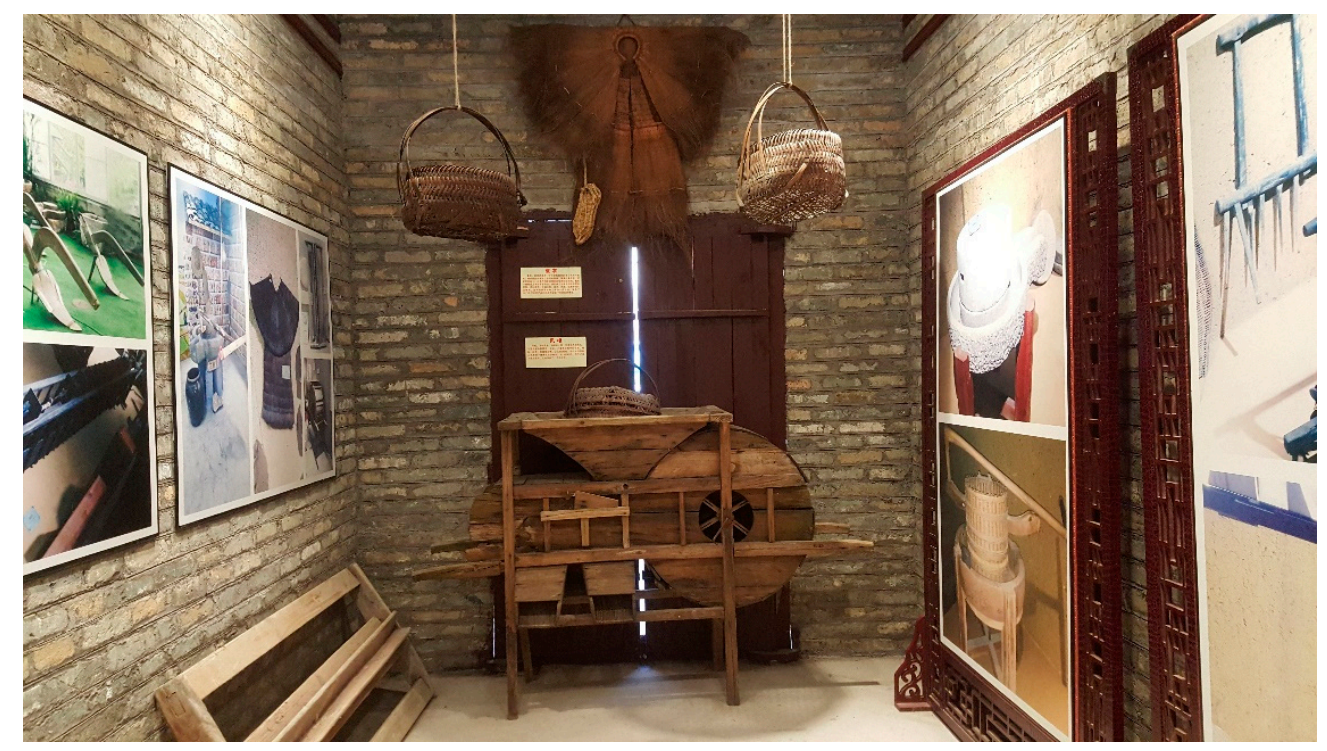

Figure 10. Traditional farming tools displayed in the Farm Culture Exhibition Hall.

Handmade firecrackers are one of the highlighted village's features. Firecracker workshop had a history of more than 100 years in Nalu Village. This kind of traditional handicraft, which was made in leisure time and sold during festivals, had become a major way of livelihood in Nalu Village. Until the 1980s, firecrackers were an important source of income for the village. Due to the strict management of firecrackers and the impact of industrialization of firecrackers production, this handicraft industry dominated by family workshops was gradually eliminated by the market. The tools for making firecrackers have also become the epitome of the village (Figure 11).

Whether it is a creation of a nostalgic sense of traditional space, or farming culture display, or the combination of these attract many tourists. This development transforms the ancient architecture of Nalu Village to a diversified cultural stage. As Nitzky pointed it out, the top-down government-led ecomuseum approach has become the impetus for reconfiguring villagers' relationships with their cultural heritage and has recently created spaces where different articulations of culture, memory, meaning, and values are expressed, negotiated, and contested [90]. The use of traditional space in Nalu Village reflects this complexity and political-cultural dimension. 


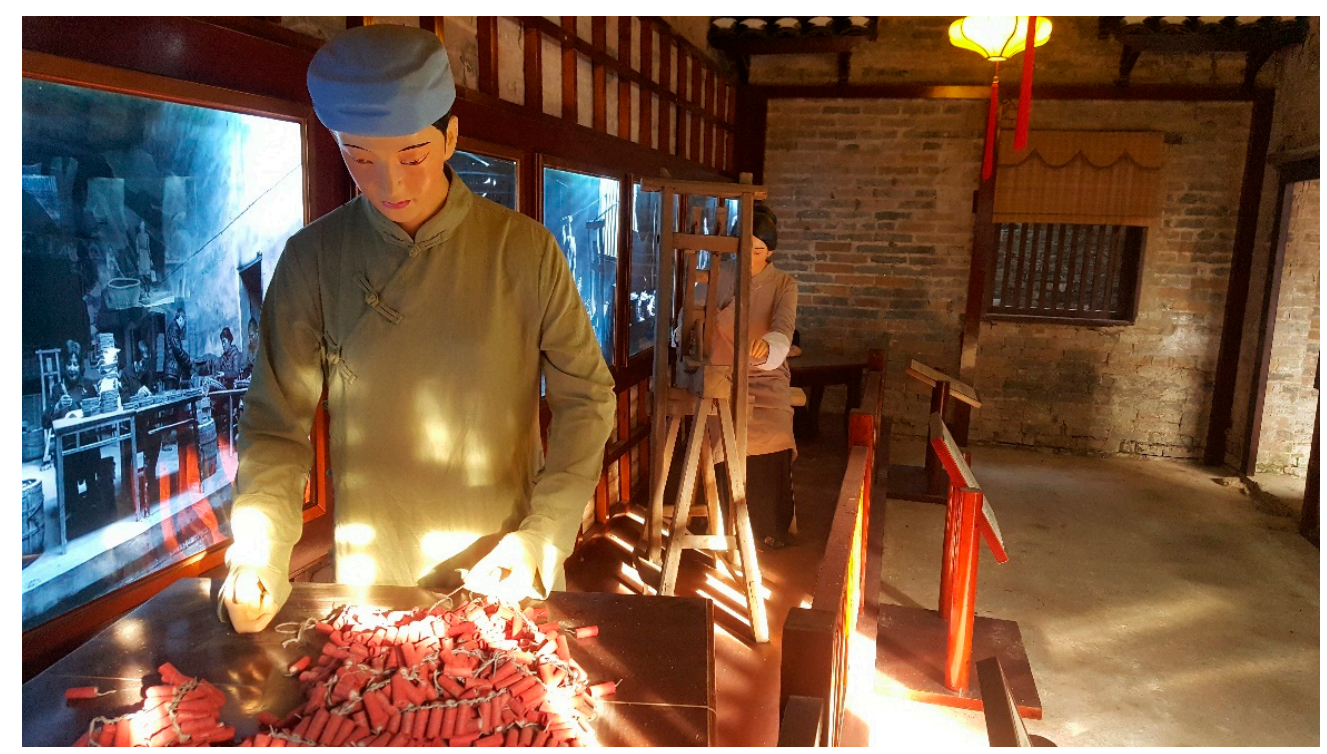

Figure 11. Traditional handmade firecrackers on display.

4.2.2. Continuous Improvement of Infrastructure Highlighting the Elements of Valued Traditions

The management of tangible heritage is reflected in the "new social integration mechanism" [91] in which the production, distribution, communication, and cooperation of villages are networked. Continuous improvement of the village infrastructure is considered one of most important achievements made by the villagers with the support of the government. These constructions make the village look like a modern rural community. Since 2014, the local government has invested more than 13 million Yuan (about US\$ 2 million) in Nalu Village in the name of "China traditional village" to repair ancient buildings and build infrastructure. In just a few years, the infrastructure of Nalu Village has been continuously improved. The main roads to the village have been widened (Figure 12); the road around the village and the bridge to the village have been built, after it was damaged by the flood in 2005, and a road access for cars to each household has been constructed.

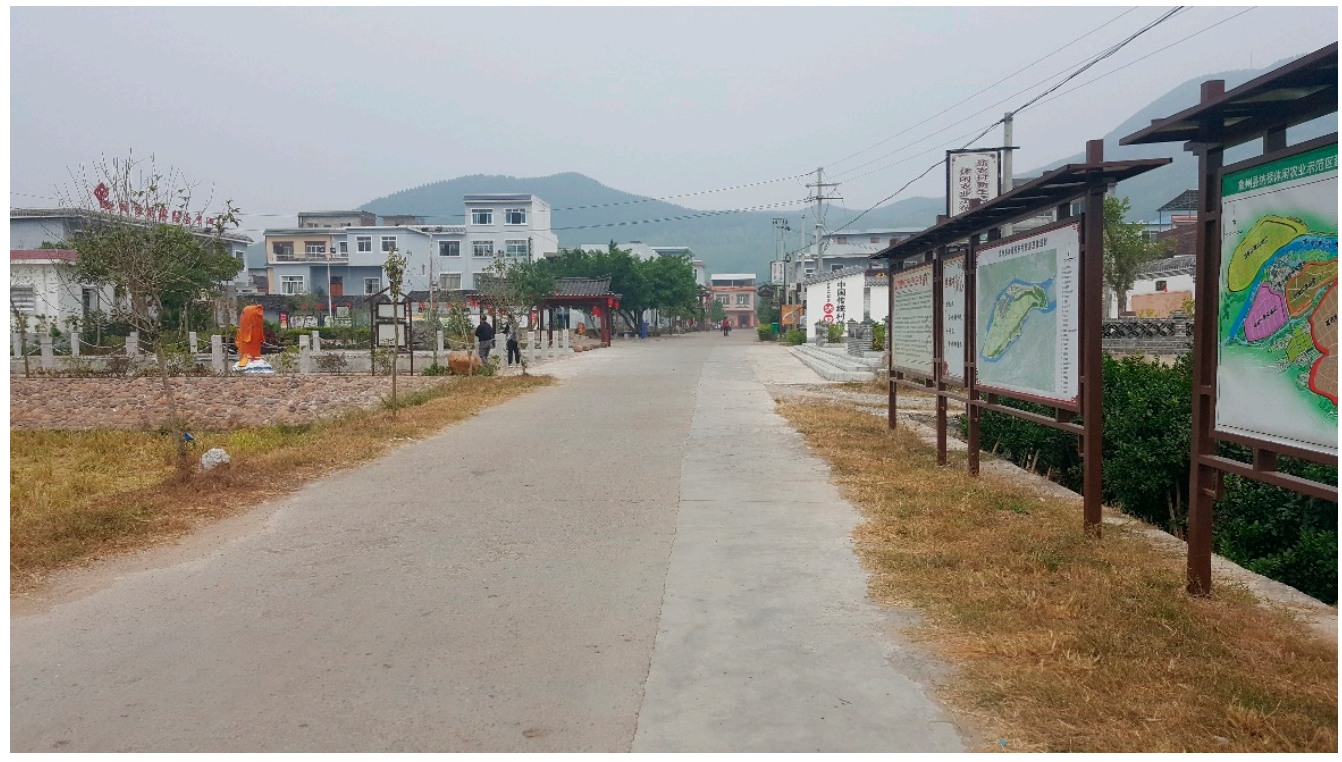

Figure 12. The main road to Nalu Village.

Nalu Village also built a new visitor center, parking lot, standardized basketball court, public restroom (Figure 13), dustbin, landscape pond, green plants belt, and guide signs 
(Figure 14). In addition, the water diversion system into the village was reconstructed with the proposal of the villagers. A canal in front of the village was rebuilt, and a pavilion was built in the canal to facilitate the access to the water for washing clothes, which is still a common practice of the villagers (Figure 15). There are stone tables and benches with chessboards under the trees at the side of the main road in the village, which are convenient for the villagers to entertain and chat during their spare time.

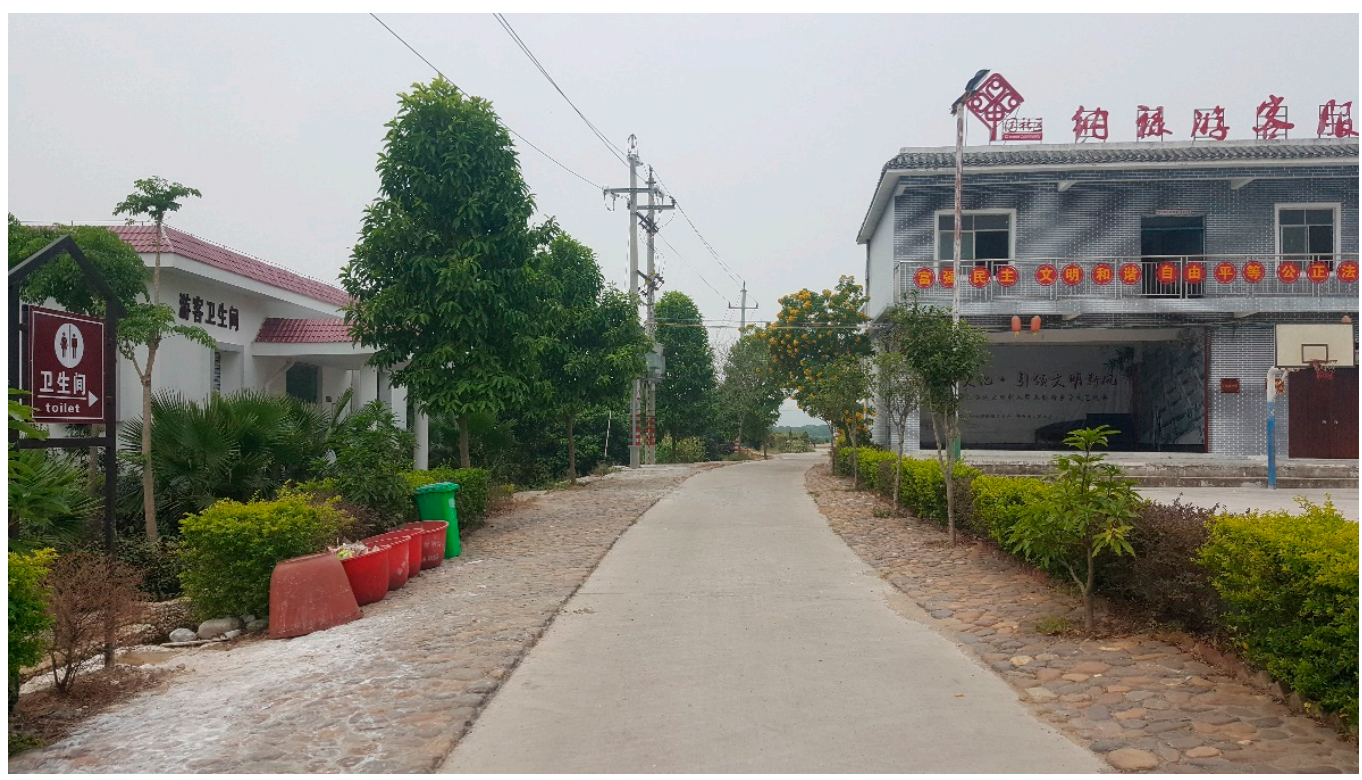

Figure 13. Tourist center and public restroom.

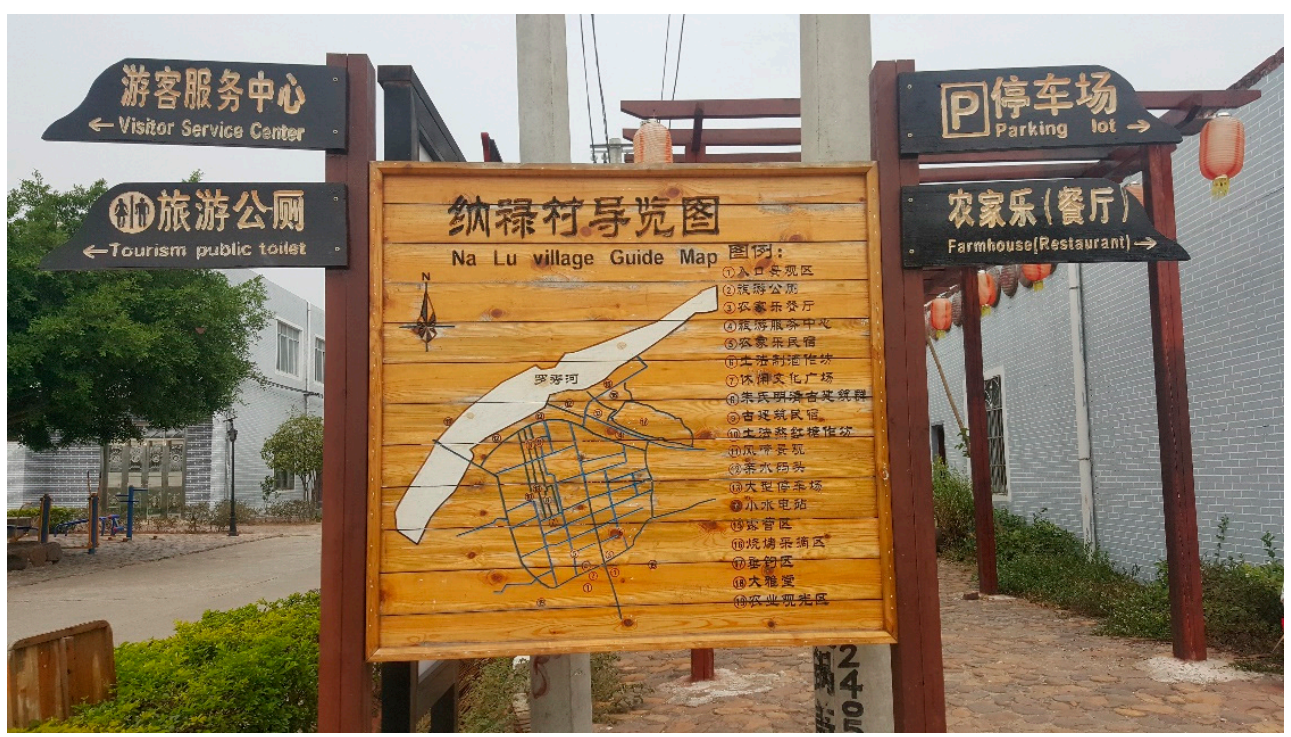

Figure 14. Guide map and signs of Nalu Village.

In order to build a traditional tourism village, the government has invested money to improve the local infrastructure, which has become an important achievement to improve the local living conditions and health conditions. It is the most recognized and proud construction achievement of the local villagers. 


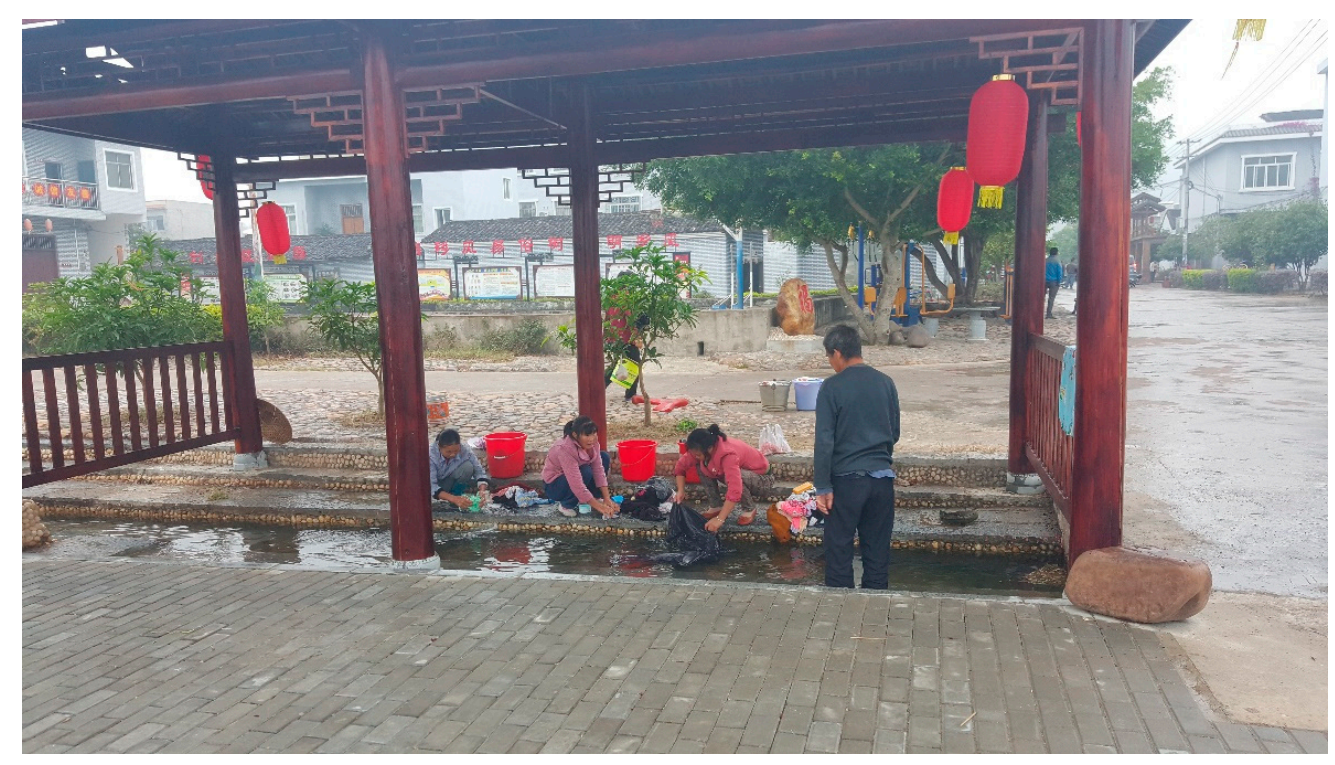

Figure 15. A pavilion for washing clothes.

\subsubsection{Promoting Traditional Festival Activities and Upgrading Services}

Intangible cultural heritage is also an important aspect to attract tourists and bring consumption. That is why today's people continue to pursue the activation of heritage. Just as Sandie Dawe says that Britain heritage is not presented "in aspic" but includes living, breathing, and vibrant places that belong as much in the present as in the past [92]. In other words, multi-party cooperation and participation in development is particularly important. The revival of rural intangible cultural heritage should include traditional festival activities, folk arts, to name a few, in which tourists can participate and experience the local culture.

In the process of developing rural tourism, the local government and villagers creatively set up farming culture experience area for tourists. This specifically attracts tourists from cities who can have a taste of rural farming experience. Before people enter Nalu Village, sugar orange fruit trees in large-farm scale appears in front of them. If it is the seeding season, visitors can participate in the rice farming process in the field or choose to experience the fruit picking in the field. Farming culture experience area has become a major attraction in Nalu Village.

The above efforts in the first few years did not receive the expected revenue. Although there is an increasing number of tourists every year, one village administrative staff said, "most of them come here to take photos (Figure 16) and are unwilling to stay overnight. Tourists still complain that they have no local products to buy." This is the most mentioned problem by village cadres of Nalu Village. After continuous exploration and reflection, the local government and villagers began to provide "extended offer", combining wonderful artistic activities, authentic local products, and specialized services, which guarantee a unique and high value offer for more customers.

One project is to promote one of the Zhuang traditional festivals "March 3" to nonZhuang visitors. Traditionally, Zhuang people in Guangxi worship their ancestors on March 3 every year. Usually, banquets are held after ceremonies. In order to make this festival more vibrant to outsiders, "young folks singing" to each other has been added as an event for celebration. This type of singing has been a traditional ritual for courtship.

In addition, the local tourism department transforms Nalu Village from an ordinary village to a scenic destination. The popularity of Nalu Village is constantly improving in the local area, and the number of tourists is increasing year by year. In 2017, the local government also held a staged wedding ceremony in the village to showcase the marriage customs of Zhuang people as a way to promote unique rituals to visitors. More traditional practices such as dances, competitions, and dramas have been gradually added to the developments. 


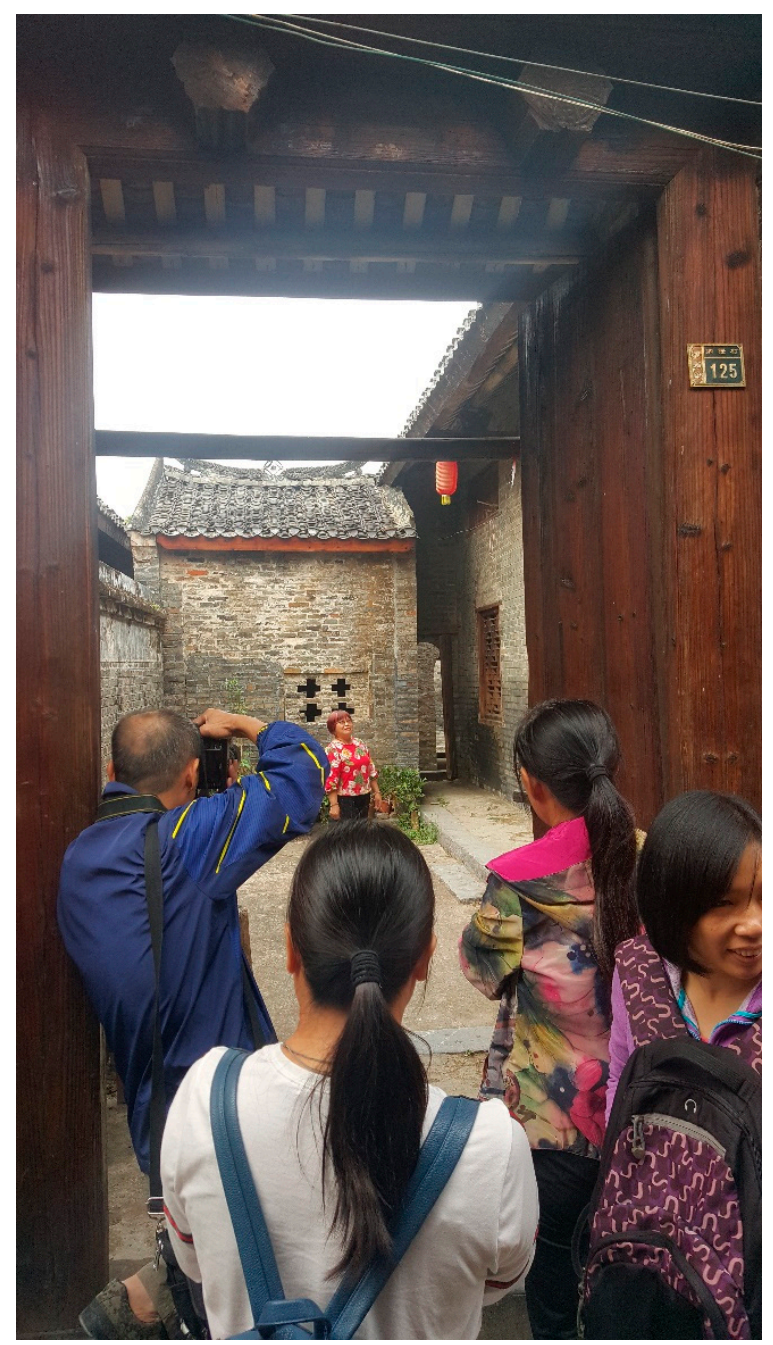

Figure 16. Tourists taking photos in ancient buildings.

In 2019, Nalu Village held an iconic activity entitled "Colorful March 3 Nalu New Era". In the ceremony, there were Zhuang dances, traditional folk customs, and zither performance on a beach. The beach sport utility vehicle (SUV) exhibition also attracted a large number of tourists. Other performances and shows were held simultaneously in the ancient buildings.

Another major breakthrough is to introduce rural e-commerce to Nalu Village. As Mr. Lang, one of the planners of the sustainable development of traditional villages, proudly stated:

"I'm very optimistic about Nalu Village's e-commerce business. I plan to create a variety of hand-made products and agricultural products here, which will be packaged and then sold online. I plan to develop local agricultural products here, such as local sugar, wine, sweet potato chips and so on. In the near future, we will have more unique products and plans to have them enter the market."

The positive economic development is a result of the combination of its natural beauty, rich cultural resources of Nalu Village, and the active participation of local villagers and the local government. This has become a local benchmark for the country's Rural Revitalization Strategy. In the end of 2017, Nalu Village was recognized as a "four-star rural tourism area", the second-best quality assessment in Guangxi Zhuang Autonomous Region. In 2020, Nalu Village earned another award. It was named as "Villages with Chinese Minority Characteristics" by the State Ethnic Affairs Committee. 


\subsection{Recognizing the Cultural Values of The Village}

In the process of becoming a traditional village, especially in the process of developing rural tourism, the villagers of Nalu Village experienced a process from "understanding" to "identification" and then to "interpretation" about who they are. Thus, its influence on local identity, sense of pride and belonging, inter- and intra-generational communication, and social links (social capital) should also be taken into account [23].

The village's popularity in China rises along its increasing publicity. Tourists come from Beijing, Hong Kong, Tianjin, Taiwan, Nanning, Wuzhou, and Liuzhou. Faced with constant questions from tourists and visitors, people in Nalu Village began to think about an existential question: who are we? What is the uniqueness of our collections and attractions?

Most villagers were not conscious about their family history before. In the beginning of this study, an interviewee was not able to tell the story of his ancient house clearly. However, two years later, in 2019, he had become the local "tour guide". He was able to testify of his own attitudinal transformation: "I have the keys to the old house. I take tourists to visit it almost every week. It is more than opening and closing the doors, but also answering the visitors' questions. There are all kinds of questions." As a result, this villager kept learning, looking for answers from Zhu's genealogy, and deliberately consulted those who knew the history of the village.

Some independent travelers also visit the village and causally speak with different residents. Like the villagers interviewed above, more and more villagers are facing questions from tourists. They sometimes feel embarrassed because they cannot answer their questions. Now, their knowledge about the village makes many tourists happy. Mr. Zhu expressed his gratitude: "The visitors always pay special attention to our history. When they know that our village is hundreds of years old, they are always amazed and admire how we are able to sustain the continuity of the village".

Leaders of the village have been playing an active role in investigating its history. Their understanding and appreciation of their home has added to the village's ever-evolving living. One of the pervious leaders was a well-praised singer in the village. He not only sang traditional songs, but also composed new songs with new verses that expressed his feelings toward the changes taken place in the village. His songs have become a new documentation and interpretation of the current history of the village. The current village leader is fond of poetry. He periodically posts his poems in couplet style on different doors as decoration. Similar to the songs, these poems document the village's development and interpret the meanings of its development in a hopeful fashion.

As the village continuously gains its popularity, some TV stations come to make documentary films about the village and some stations use the village as a backdrop for their dramas and programs. A major official of the local town government expressed his view on the development of Nalu Village: "It has a simple folk custom and a strong spirit of collectivism. It can work with the government to carry out various activities and programs. We are willing to hold an important event here, such as Culture Festival on March 3 every year. The result should be very good." In short, the villagers expressed excitement and pride when they speak of the transformation of their home and village.

\section{Diversifying Livelihood}

After learning about the tourists' motivation and expectation, Nalu Village began to provide diversified services. This has directly led to the emergence of diversified local livelihoods. Although rural tourism around heritage is not the main economic income of the village, these actions are adjusting the local economic structure, and constantly internalizing the resources, history, tradition, and culture of the village, thus making it more powerful. Driven by rural tourism, the villagers of Nalu Village began to organize the production of local products. These local specialties include traditional food and handicrafts. In every large-scale reception, local traditional food, such as five-color rice, handmade rice cake, zongzi (粽子), Ciba (糍粑), and so on are presented. Local-made sugar (Figure 17), traditional wine, hand-made Yuba (dried rice noodle) (Figure 18), fermented 
baby ginger, and so on, have been articulated as the traditional food of the village. In handicraft industry, there are root carving and bamboo weaving products. Villagers have received financial returns from rural tourism, and they have also begun to consciously participate in the layout of rural tourism with government guidance. A villager, Ms. Wei, said that all her farms had been contracted out to grow fruits. She was often relaxed at home. Seeing more and more tourists in the village, she planned to open a rice noodle shop in the village. Another villager, Mr. Pan, often promoted his local products to visitors in a local grocery store. The first restaurant managed by Mr. Jia in Nalu Village has been successful operating for more than six years (Figure 19).

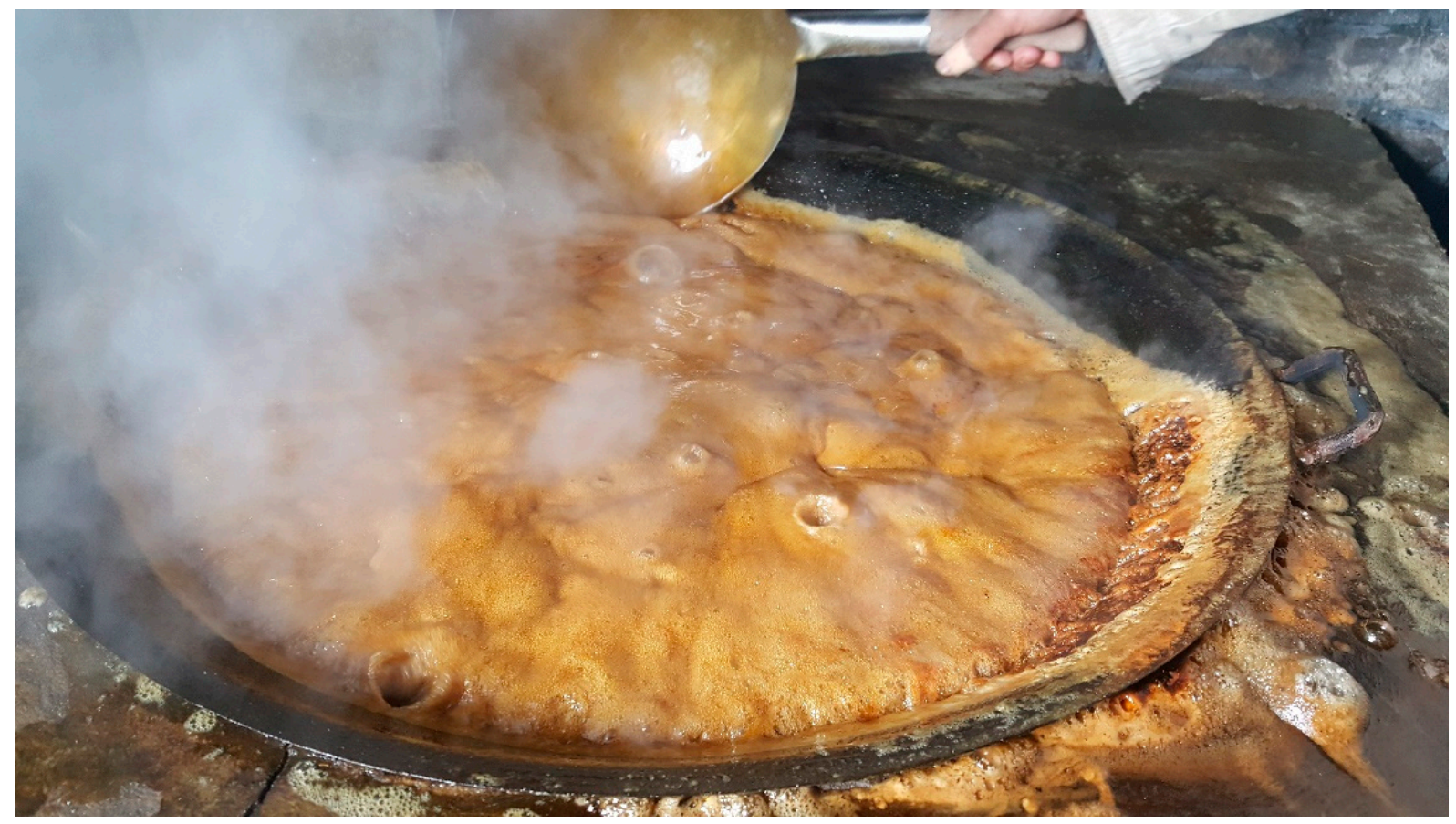

Figure 17. Traditional home-made sucrose.

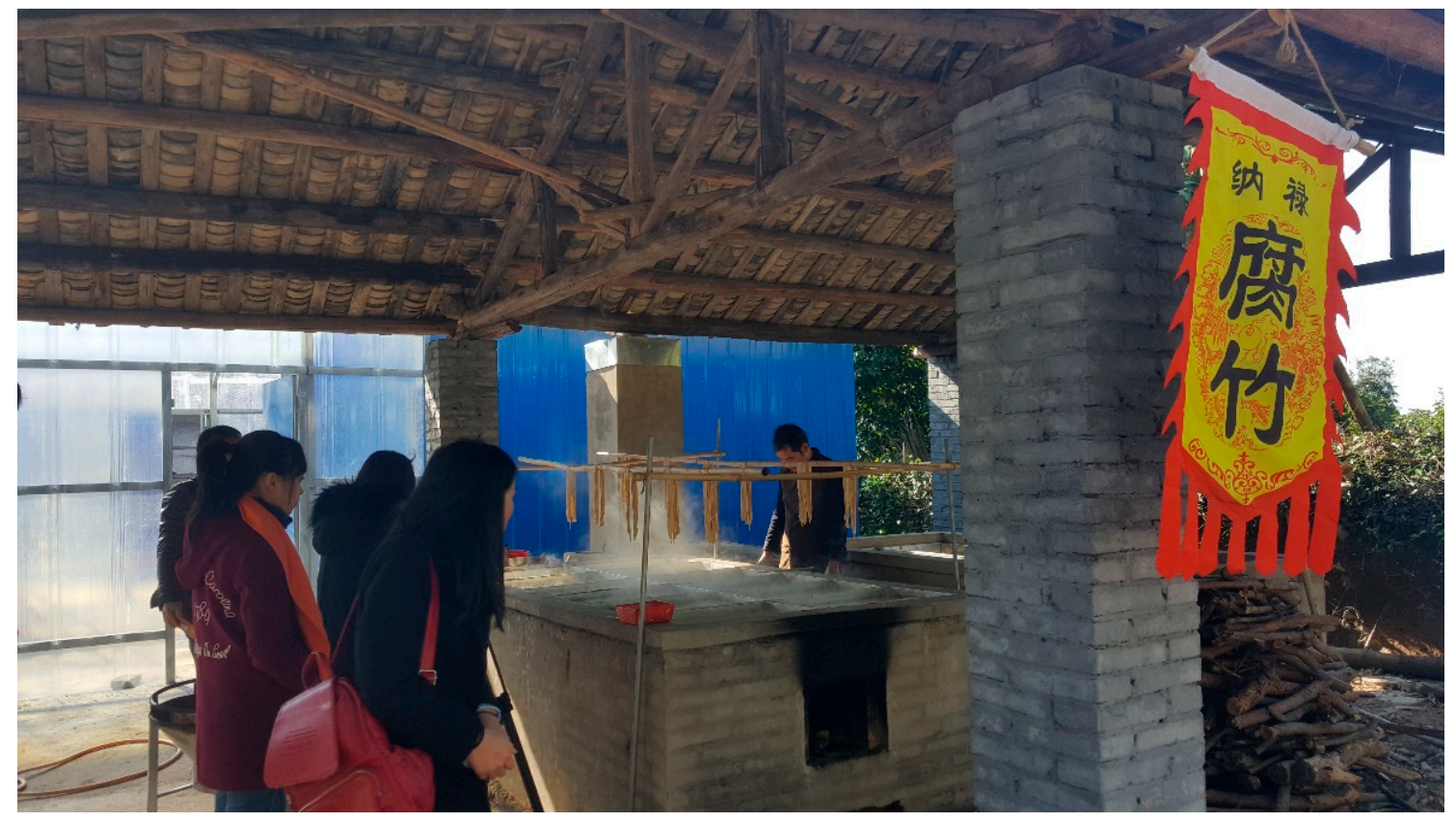

Figure 18. Making local specialty Yuba. 


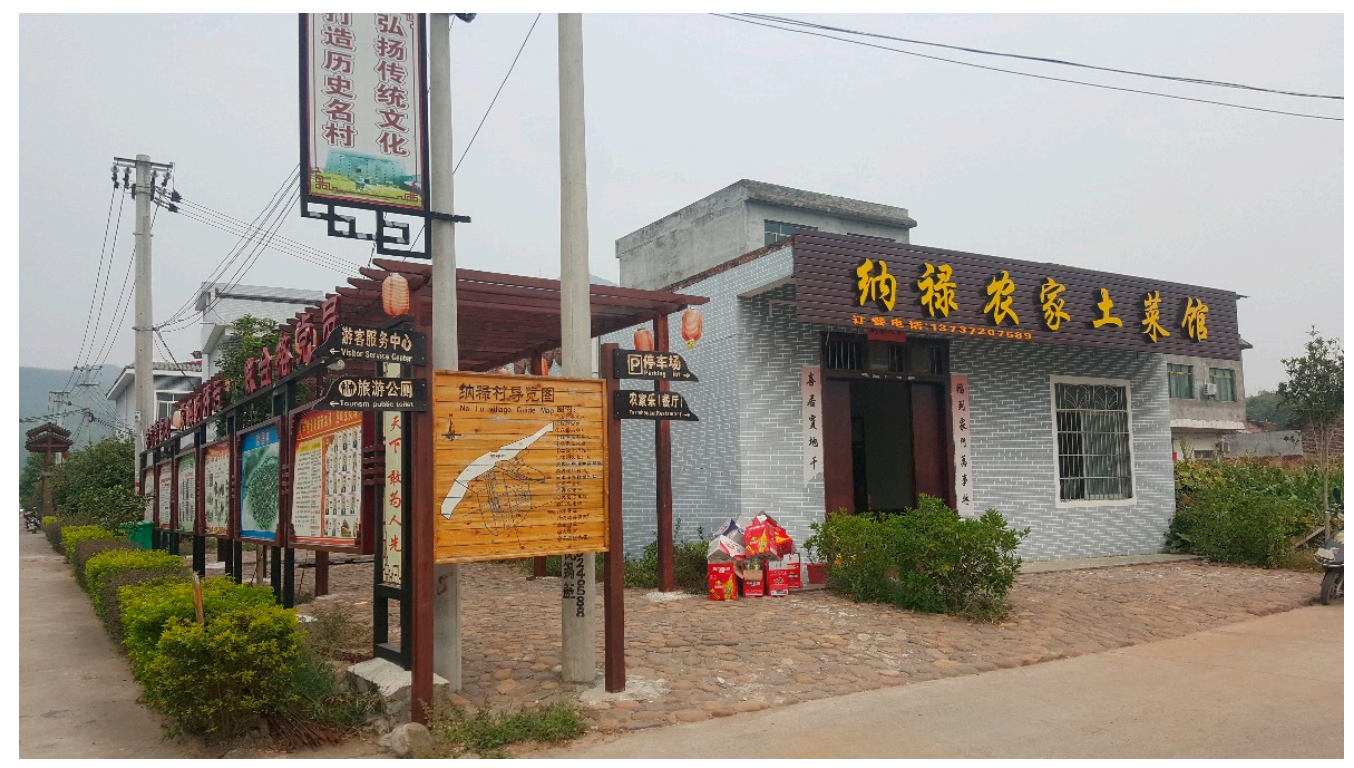

Figure 19. The first restaurant in Nalu Village.

Villagers have begun to realize that the title of Chinese traditional village brings new development opportunities to their village. Mr. Wei, head of Nalu Village, said: "we just want to make good use of the golden signboard of 'China Traditional Village' to develop tourism, so that tourists can have fun and enjoy themselves, and create more economic opportunities for the people in Nalu Village". In 2019, the government built a memorial archway at the entrance of Nalu Village and planned to set up a large parking lot on the right side of the memorial archway which is about one kilometer away from village ancient buildings. "If the conditions are ripe, it will become a tourist attraction. Now the memorial archway is the gate of the scenic spot. The ticket office will be set up here, and most tourists' vehicles will park in the designated place," a local village cadre said. In term of the satisfaction of tourists and the efficiency of tourism management, the construction of parking area has been put on the agenda.

\section{Discussion and Conclusions}

The designation of an ancient village that is about to disappear sparks a new journey of its protection and development, and the village has a chance to redevelop. Its livelihood is also moving towards vitality and diversity. Naming of Chinese traditional village also becomes the opportunity and booster of villagers' unity [93]. Nalu Village has discovered the multiple values of its familiar and underdeveloped culture. All agents involved in this village's development re-examine the ancient architecture and cultural meaning and revive the traditional food and handicrafts that are about to disappear. These actions have become the beginning of a new sustainable development.

This study reveals several important theoretical implications on sustainable development of a village that has a rich history and culture. Drawing from the literature reviewed above, this research took a more holistic approach to examine a village. The research finding suggests that the naming a village as a heritage site does not necessarily equate to sustainable development, nor does it mean that the "naming" will spontaneously encourage sustainable development. It takes many factors that work together to construct the abstract meaning of the naming. The involved parties retain and develop the substances such as everyday living and activities that keep the life of the village being sustainable through which the new generations can continue to appreciate the values of their past.

This case indicates that bearing a name of "traditional village" is not sufficient to ensure its sustainable continuity, even though the villagers develop affection towards their living experiences in the place. Its development requires a collaborative effort of many parties after obtaining the name. The process of Nalu Village "becoming" a "traditional 
village" is a process of rediscovering the value of history and heritage, which itself is a kind of continuous effort to link the present to the past. There is no doubt that constructions and naming of the places are a marketing strategy where villagers draw inspiration, ideas, resources, and discoveries from their culture, and there is no sure way of ascertaining whether this is a purely economic drive, cultural drive or both [94] (p. 12).

The success of Nalu Village requires three conditions to flourish: (1) the rich history and heritage in the village; (2) the conscious recognition of its value not only by the residents but also the state; and (3) the programs or projects that can utilize its values to generate important resources for sustainable development, namely tourism and flexible mode of economic productions. The interactive effort among these three conditions nurtures the pride of villagers which in turn makes them cherish the history of the village and promote the development of rural tourism. Intervention from external forces may help rediscover the history and culture and reevaluate the traditional values of the place. Naming from the state can be regarded as an important boosting force, which enables the re-recognition of the value of local history and heritage, and at the same time protect and develop it innovatively. It acts as an attraction force for people from different places of origin, while it stimulates local socio-economic development and reinforces a sense of local identity and pride [95] (P2). This ideal strategy promotes sustainable development of rural areas.

Becoming a traditional village is not a return to its static traditionalism, but a transformation and connection to a larger world, thus promoting economically sustainable development. Only through this kind of direct contact between urban and rural areas, the two social and cultural elements of vernacular and tourism can communicate and transform creatively [96]. The state's designation of a village is not only an affirmation of the object of the name, but also a seal of approval. The state's recognition of the traditional villages has stimulated the enthusiasm of the villagers and the local government. It also attracts more social interests, including investors and entrepreneurs, tourists, and social institutions such as schools, media, scientific research institutions, and so on, to the place. In this series of interactive process, needs and information are fully exchanged, so as to promote the sustainable rural development. As a source of strengths for the communities and individuals, heritage culture is demonstrated that both tangible and intangible dimensions are intertwined [97]. We need to examine it in a larger context of time.

At the end of this research, there were some new developments. A tourism development company had signed a contract with the Xiangzhou County Government to develop tourism, and planned to invest 31 million Yuan (about US\$ 4.8 million) in Nalu Village's tourism. Under the leadership of the county government, these are still an ongoing development. Whether these "discoveries" are commonly marked as an explicit and sometimes self-conscious way of negotiating social and cultural identity, value and meaning [98] (p. 4), or depicting the tensions that have played out among different voices in the process of creating meanings and understandings centered on the village's heritage [99] remains to be investigated. The state's designation of a traditional village will certainly bring more resources, open new opportunities and integrate the formerly isolated place to the larger world. What unforeseeable future these capitals will bring to Nalu Village is too early to conclude. In addition, how to improve governance to overcome the difficulty of balancing the interests of multiple parties in public heritage management remains to be further observed. The findings of this study could serve as a steppingstone for an "action research" to guide or intervene in Nalu Village's future development. Overall, a longitudinal study of this village deserves scholars', policy makers', and investors' close attention.

Author Contributions: Conceptualization, R.J.Q. and H.H.L.; methodology, R.J.Q.; formal analysis, R.J.Q. and H.H.L.; investigation and photos, R.J.Q.; writing-original draft preparation, R.J.Q.; writing-review and editing, R.J.Q.; H.H.L.; supervision, H.H.L. All photos were taken by R.J.Q. All authors have read and agreed to the published version of the manuscript. 
Funding: This work was supported by a research grant [GXUN-CHXBC201801] for the Excellent Ph.D. Candidate Study Abroad Program funded by the Guangxi Postgraduate Education Innovation Program.

Institutional Review Board Statement: Not applicable.

Informed Consent Statement: Informed oral consent.

Data Availability Statement: Secondary data such as government policies etc. available in a publicly accessible repository.

Acknowledgments: Thanks are extended to the Department of Education of Guangxi Zhuang Autonomous Region and Guangxi University for Nationalities for their financial support. Hu Dejian's important contribution, as the research assistant to this research project, is greatly appreciated. Sincere gratitude is expressed to the special issue editor and three anonymous reviewers for providing valuable and extensive feedback on an earlier draft of this paper.

Conflicts of Interest: The authors declare no conflict of interest.

\section{References}

1. Liu, B.; Ren, C. How to Develop Chinese Rural Tourism in the Context of New Urbanization? Asian Agric. Res. 2016, 8, 27-32.

2. Gu, C.; Guan, W.; Liu, H. Chinese urbanization 2050: SD modeling and process simulation. Sci. China Earth Sci. 2017, 60, 1067-1082. [CrossRef]

3. Notional Bureau Statistics. Statistical Bulletin of National Economic and Social Development of the People's Republic of China in 2019. Available online: http://www.stats.gov.cn/tjsj/zxfb/202002/t20200228_1728913.html (accessed on 9 January 2021).

4. Yulin, Z. Great Clearances: The Chinese Version of Enclosure Movement, 1991-2013. China Agric. Univ. J. Soc. Sci. Ed. 2015, 32, $19-45$.

5. Zhou, Z.P. China's rural population hollowing out and its challenges. Popul. Res. 2008, 32, 45-52. [CrossRef]

6. Chen, J.X.; Liu, W.Y. The formation form and governance path of rural hollowing in China. Acad. J. Zhongzhou. 2012, 05, 103-106.

7. Jia-jun, X.; Meng, Z. The present situation and governance path of the rural population hollowing in China. Hubei Agric. Sci. 2020, $59,208$.

8. Li, Y.C. Feng Jicai checks up folk culture resources: Feng Jicai, vice chairman of China Federation of Literary and Art Circles, launched the rescue project of Chinese folk cultural heritage. Democracy 2003, 04, 34-37.

9. Ministry of Housing and Urban-Rural Development. Traditional Village Evaluation and Identification Index System (Trial). Available online: http://www.mohurd.gov.cn/wjfb/201208/t20120831_211267.html (accessed on 4 January 2021).

10. Integrated Information Form. Available online: http:/ /www.mohurd.gov.cn/ (accessed on 6 January 2021).

11. World Heritage Centre-Official Site. Available online: https://whc.unesco.org/en/criteria/ (accessed on 9 February 2021).

12. International Council on Monuments and Sites. Available online: https://www.icomos.org/en/about-icomos/mission-andvision/icomos-mission?start=1 (accessed on 9 February 2021).

13. Robertson, M. Sustainability Principles and Practice; Taylor \& Francis: Abingdon, UK, 2017; p. 25.

14. Caradonna, J.L. Sustainability: A History; Oxford University Press: Oxford, UK, 2014; pp. 11, 117.

15. Spindler, E.A. The History of Sustainability the Origins and Effects of a Popular Concept. In Sustainability in Tourism: A Multidisciplinary Approach; Jenkins, I., Schröder, R., Eds.; Springer Fachmedien Wiesbaden: Wiesbaden, Germany, 2013; pp. 9-31.

16. Cohen, T. Telemorphosis: Theory in the Era of Climate Change; Open Humanities Press: London, UK, 2012; Volume 1, p. 19.

17. Caradonna, J.L. Routledge Handbook of the History of Sustainability; Taylor \& Francis: Abingdon, UK, 2017 ; p. 37.

18. Murzyn-Kupisz, M. Cultural, economic and social sustainability of heritage tourism: Issues and challenges. Econ. Environ. Stud. 2012, 12, 113-133.

19. Pizam, A. Tourism manpower: The state of the art. J. Travel Res. 1982, 21, 5-9. [CrossRef]

20. Vaughan, D.R. The cultural heritage: An approach to analyzing income and employment effects. J. Cult. Econ. 1984, 8, 1-36. [CrossRef]

21. Milewski, D. Mnożnik turystyczny. In Ekonomika Turystyki; Panasiuk, A., Ed.; PWN: Warszawa, Poland, 2007 ; pp. 54-59.

22. Murzyn-Kupisz, M. Sustainable approaches to natural environment and cultural heritage. Two sides of the same coin? Econ. Environ. Stud. 2010, 10, 379-397.

23. Murzyn-Kupisz, M. The socio-economic impact of built heritage projects conducted by private investors. J. Cult. Herit. 2013, 14, 156-162. [CrossRef]

24. Platje, J. Institutional Capital-Creating Capacity and Capabilities for Sustainable Development; Wydawnictwo Uniwersytetu Opolskiego: Opole, Poland, 2011.

25. Aas, C.; Ladkin, A.; Fletcher, J. Stakeholder collaboration and heritage management. Ann. Tour. Res. 2005, 32, 28-48. [CrossRef]

26. Chhabra, D. Sustainable Marketing of Cultural and Heritage Tourism; Routledge: Boca Raton, FL, USA, 2010.

27. Saipradist, A.; Staiff, R. Crossing the cultural divide: Western visitors and interpretation at Ayutthaya World Heritage Site, Thailand. J. Herit. Tour. 2008, 2, 211-224. [CrossRef] 
28. Barthel-Bouchier, D. Cultural Heritage and the Challenge of Sustainability; Routledge: Boca Raton, FL, USA, 2016.

29. Rakic, T.; Chambers, D. World heritage: Exploring the tension between the national and the 'universal'. J. Herit. Tour. 2008, 2, 145-155. [CrossRef]

30. Timothy, D.J. Cultural heritage and tourism: An introduction; Channel View Publications: Bristol, UK, 2011; Volume 4.

31. Throsby, D. Tourism, heritage and cultural sustainability: Three golden rules. In Cultural Tourism and Sustainable Local Development; Ashgate Publishing: Aldershot, UK, 2009.

32. Xiao, Y.; Zhao, J.; Sun, S.; Guo, L.; Axmacher, J.; Sang, W. Sustainability Dynamics of Traditional Villages: A Case Study in Qiannan Prefecture, Guizhou, China. Sustainability 2020, 12, 314. [CrossRef]

33. Maikhuri, R.K.; Semwal, R.L.; Rao, K.S.; Nautiyal, S.; Saxena, K.G. Eroding traditional crop diversity imperils the sustainability of agricultural systems in Central Himalaya. Curr. Sci. India 1997, 73, 777-782.

34. Liu, S.; Ge, J.; Li, W.; Bai, M. Historic environmental vulnerability evaluation of traditional villages under geological hazards and influencing factors of adaptive capacity: A district-level analysis of Lishui, China. Sustainability 2020, 12, 2223. [CrossRef]

35. Huang, Q.Y.; Xi, X.S. Vernacular Landscape Leading the Way: The Holistic Protection and Revival of Hani's Ancient Village under the Background of Yuanyang Terraced Fields' Register on the World Heritage, Advanced Materials Research, 2014; Trans Tech Publications: Stafa-Zurich, Switzerland, 2014; pp. 2468-2488.

36. Liu, M. The Protection and Heritage Strategy of Chongqing Mountain Traditional Villages-An Example of Xiushan County Zhongling Town Chenjiaba Traditional Village Protection Planning, Applied Mechanics and Materials, 2014; Trans Tech Publications: Stafa-Zurich, Switzerland; pp. 348-355.

37. Čustović, H.; Kovačević, Z.; Tvica, M. Rural Ecology; University of Sarajevo: Sarajevo, Bosnia and Herzegovina, 2013.

38. Chang, K.; Chou, P. Integrating Intelligent Living, Production and Disaster Prevention into a Sustainable Community Assessment System for the Rural Village Regeneration in Taiwan, 2011 International Conference on Multimedia Technology, 2011; IEEE: New York, NY, USA, 2011; pp. 6410-6413.

39. Dumreicher, H. Chinese villages and their sustainable future: The European Union-China-Research Project "SUCCESS". J. Environ. Manag. 2008, 87, 204-215. [CrossRef]

40. Chambers, R.; Conway, G. Sustainable Rural Livelihoods: Practical Concepts for the 21st Century; Institute of Development Studies (UK): Falmer, UK, 1992.

41. Ma, J.; Zhang, J.; Li, L.; Zeng, Z.; Sun, J.; Zhou, Q.B.; Zhang, Y. Study on livelihood assets-based spatial differentiation of the income of natural tourism communities. Sustainability 2018, 10, 353. [CrossRef]

42. Xia, B.; Zuo, J.; Skitmore, M.; Buys, L.; Hu, X. Sustainability literacy of older people in retirement villages. J. Aging Res. 2014, 2014, 919054. [CrossRef]

43. Fan, K.; Zhong, X.; Xu, Y.; Zhang, B. Constructing an Efficient Model to Inspire Design Education Sustainability in Rural Areas. Sustainability 2018, 10, 3562. [CrossRef]

44. Hlalele, D. Sustainable rural learning ecologies-a prolegomenon traversing transcendence of discursive notions of sustainability, social justice, development and food sovereignty. Td: J. Transdiscipl. Res. S. Afr. 2013, 9, 561-580. [CrossRef]

45. Akpinar, N.; Talay, I.; Ceylan, C.; Gündüz, S. Rural women and agrotourism in the context of sustainable rural development: A case study from Turkey. Environ. Dev. Sustain. 2005, 6, 473-486. [CrossRef]

46. Henderson, J. Heritage, Identity and Tourism in Hong Kong Joan Henderson. Int. J. Herit. Stud. 2001, 7, 219-235. [CrossRef]

47. Harvey, D.C. Heritage Pasts and Heritage Presents: Temporality, meaning and the scope of heritage studies. Int. J. Herit. Stud. 2001, 7, 319-338. [CrossRef]

48. Nijkamp, P.; Riganti, P. Assessing cultural heritage benefits for urban sustainable development. Int. J. Serv. Technol. Manag. 2008, 10, 29-38. [CrossRef]

49. UNESCO. Available online: https://whc.unesco.org/en/convention/ (accessed on 13 February 2021).

50. UNESCO. Available online: https://whc.unesco.org/en/decisions/1217/ (accessed on 13 February 2021).

51. UNESCO. Available online: https://whc.unesco.org/en/decisions/5197/ (accessed on 13 February 2021).

52. World Heritage Centre-Official Site. Available online: http://whc.unesco.org/en/list/stat (accessed on 4 January 2021).

53. Williams, K. The Meanings and Effectiveness of World Heritage Designation in the USA; Taylor Francis Group: Abingdon, UK, 2004.

54. Council of Europe. Available online: https://www.coe.int/en/web/landscape (accessed on 13 February 2021).

55. Lowenthal, D. The Heritage Crusade and the Spoils of History; Cambridge University Press: Cambridge, UK, 1998 ; p. 226.

56. Hall, S. Representation: Cultural Representations and Signifying Practices; Sage: Thousand Oaks, CA, USA, 1997 ; Volume 2, p. 61.

57. McAreavey, R.; McDonagh, J. Sustainable rural tourism: Lessons for rural development. Sociol. Rural. 2011, 51, 175-194. [CrossRef]

58. Wheeller, B. Heritage Tourists: Responsible, (f)or What? Tour. Recreat. Res. 2009, 34, 84-87. [CrossRef]

59. Zhang, C.W. On the improvement of the legal system of cultural heritage protection. Shandong Soc. Sci. 2011, 10, 81-84.

60. Serraino, M.; Lucchi, E. Energy efficiency, heritage conservation, and landscape integration: The case study of the san martino castle in parella (turin, italy). Energy Procedia 2017, 133, 424-434. [CrossRef]

61. Amir, A.F.; Ghapar, A.A.; Jamal, S.A.; Ahmad, K.N. Sustainable tourism development: A study on community resilience for rural tourism in Malaysia. Procedia-Soc. Behav. Sci. 2015, 168, 116-122. [CrossRef]

62. Coccossis, H.; Nijkamp, P. Planning for Our Cultural Heritage; Avebury: Aldershot, UK, 1995.

63. Richards, G.; Hall, D.R. Tourism and Sustainable Community Development; Psychology Press: East Sussex, UK, 2003 ; Volume 7. 
64. Wikipédia. Available online: https://fr.wikipedia.org/wiki/Les_Plus_Beaux_Villages_de_la_Terre (accessed on 12 February 2021).

65. The Federation of the Most Beautiful Villages of the World. Available online: https://lpbvt.org/ (accessed on 12 February 2021).

66. United Nations. Ending Poverty. Available online: https://www.un.org/en/sections/issues-depth/poverty/index.html (accessed on 3 January 2021).

67. Peer, A. Global Poverty: Facts, FAQs, and How to Help. Available online: https://www.worldvision.org/sponsorship-newsstories/global-poverty-facts (accessed on 10 January 2021).

68. Kharas, H.; Hamel, K. Turning back the Poverty Clock: How will COVID-19 impact the world's poorest people. Brook. Retrieved Novemb. 2020, 18, 2020.

69. National Bureau of Statistics. Data of 2019. Available online: https:/ / data.stats.gov.cn/easyquery.htm? cn=C01\&zb=A0301\&sj=20 19 (accessed on 6 January 2021).

70. Gao, J.; Wu, B. Revitalizing traditional villages through rural tourism: A case study of Yuanjia Village, Shaanxi Province, China. Tour. Manag. 2017, 63, 223-233. [CrossRef]

71. Butler, L.M.; Mazur, R.E. Principles and processes for enhancing sustainable rural livelihoods: Collaborative learning in Uganda. Int. J. Sustain. Dev. World Ecol. 2007, 14, 604-617. [CrossRef]

72. Li, Y.; Fan, P.; Liu, Y. What makes better village development in traditional agricultural areas of China? Evidence from long-term observation of typical villages. Habitat. Int. 2019, 83, 111-124. [CrossRef]

73. Shi, T.; Gill, R. Developing effective policies for the sustainable development of ecological agriculture in China: The case study of Jinshan County with a systems dynamics model. Ecol. Econ. 2005, 53, 223-246. [CrossRef]

74. Xue, L.; Weng, L.; Yu, H. Addressing policy challenges in implementing Sustainable Development Goals through an adaptive governance approach: A view from transitional China. Sustain. Dev. 2018, 26, 150-158. [CrossRef]

75. Cherni, J.A.; Hill, Y. Energy and policy providing for sustainable rural livelihoods in remote locations-The case of Cuba. Geoforum 2009, 40, 645-654. [CrossRef]

76. Juanwen, Y.; Quanxin, W.; Jinlong, L. Understanding indigenous knowledge in sustainable management of natural resources in China: Taking two villages from Guizhou Province as a case. For. Policy Econ. 2012, 22, 47-52. [CrossRef]

77. Vitasurya, V.R. Local wisdom for sustainable development of rural tourism, case on Kalibiru and Lopati village, province of Daerah Istimewa Yogyakarta. Procedia-Soc. Behav. Sci. 2016, 216, 97-108. [CrossRef]

78. Scoones, I. Livelihoods perspectives and rural development. J. Peasant. Stud. 2009, 36, 171-183. [CrossRef]

79. Scoones, I. Sustainable Livelihoods and Rural Development; Practical Action Publishing: Rugby, UK, 2015; p. xv.

80. [Guangxi Story] Episode 60: The Legacy of Nalu Zhu Family in Xiangzhou. Available online: http://tv.gxnews.com.cn/ staticpages/20170416/newgx58f2ea4c-16105431.shtml (accessed on 6 January 2021).

81. Friedman, E.; Pickowicz, P.G.; Selden, M. Revolution, Resistance, and Reform in Village China; Yale University Press: London, UK, 2005.

82. Zhu clan Committee of Xiangzhou. Zhu's Genealogy: The Xiangzhou Lineage of King Jingjiang of Ming Dynasty; Zhu clan Committee of Xiangzhou: Zhuhai, China, 2015; pp. 192-194.

83. Stojević, I. Village and Heritage in China: A Discussion on the Influence and Future of Heritage Work in Rural Areas. Heritage 2019, 2, 666-680. [CrossRef]

84. Liu, P.L. Ancient Villages: A Harmonious Space for People to Gather; SDX Joint Publishing Company: Shanghai, China, 1998.

85. MOHURD \& NCHA. The Seventh Batch of Famous Towns \& Villages in History \& Culture. Available online: http://www. mohurd.gov.cn/wjfb/201901/t20190130_239368.html (accessed on 6 January 2021).

86. Xiao, Z.H. Protection and development of Traditional Villages: “China Plan” Won World Praise. China Construction Daily, 5 September 2019.

87. Selman, P. What do we mean by sustainable landscape? Sustain. Sci. Pract. Policy 2008, 4, 23-28.

88. Cai Gel. Walking into the Ancient Village of Nalu, Meet Han Fu of Ming Dynasty. Available online: https://www.meipian.cn/ en79q71 (accessed on 10 January 2021).

89. Sagu Baihe Lucia. Go to an Old Village at the Weekend. Available online: https://www.jianshu.com/p/5dccb455b851 (accessed on 10 January 2021).

90. Nitzky, W. Mediating Heritage Preservation and Rural Development: Ecomuseum Development in China. Urban Anthr. Stud. Cult. Syst. World Econ. Dev. 2012, 41, 367-417.

91. Chen, Z.; Ren, X.; Zhang, Z. Cultural heritage as rural economic development: Batik production amongst China's Miao population. J. Rural Stud. 2020, 81, 182-193. [CrossRef]

92. Dawe, S. Valuing heritage tourism. In Investing in Success: Heritage and the UK Tourism Economy; Heritage Lottery Fund: London, UK, 2010.

93. Luo, C.J. From family and regional identity to "community of common destiny": The construction of embedded ethnic relationship in traditional village. Guangxi Ethn. Stud. 2020, 2, 32-40.

94. Saidi, U. Repackaging "traditional" architecture of the African Village in Zimbabwe. In Urban and Architectural Heritage CONSERVATION within Sustainability; IntechOpen: London, UK, 2018; p. 12.

95. Girard, L.F.; Nijkamp, P. Narrow escapes: Pathways to sustainable Local cultural tourism. In Cultural Tourism and Sustainable Local Development; Girard, L.F., Nijkamp, P., Eds.; Ashgate Publishing: Farnham, UK, 2009; pp. 1-9. 
96. XuDong, Z. How could be encountered between the earthbound society and tourism: A new development of rural revitalization under the perspective of cultural transformation. J. Orig. Ecol. Natl. Cult. 2020, 12, 67-74.

97. Chmutina, K.; Tandon, A.; Kalkhitashvili, M.; Tevzadze, M.; Kobulia, I. Connecting heritage, vulnerabilities and capacities through a participatory game. Int. J. Disast. Risk Res. 2021, 53, 102005.

98. Smith, L. Uses of Heritage; Taylor \& Francis: Abingdon, UK, 2006; p. 4.

99. Zhang, Y.; $\mathrm{Wu}, \mathrm{Z}$. The reproduction of heritage in a Chinese village: Whose heritage, whose pasts? Int. J. Herit. Stud. IJHS 2016, 22, 228-241. [CrossRef] 